Article

\title{
Perception of Urban Green Areas Associated with Sociodemographic Affiliation, Structural Elements, and Acceptance Stripes
}

\author{
Marco Zobec ${ }^{1, *}$, Oliver Betz ${ }^{1}$ and Philipp Andreas Unterweger ${ }^{2}[$ \\ 1 Institut für Evolution und Ökologie, Evolutionsbiologie der Invertebraten, Eberhard Karls Universität \\ Tübingen, Auf der Morgenstelle 28, 72076 Tübingen, Germany; oliver.betz@uni-tuebingen.de \\ 2 Dr. Unterweger Biodiversitätsplanung, Obere Dorfstraße 39, 88489 Wain, Germany; \\ philipp.unterweger@biodiversitaetsplanung.de \\ * Correspondence: marco.zobec@googlemail.com
}

Received: 20 December 2019; Accepted: 3 February 2020; Published: 8 February 2020

\begin{abstract}
The extensification (opposite of intensification) of urban public green spaces offers great potential for conservation. One major issue for the long-term success of such a measure is, however, its acceptance by the urban population. This contribution presents the results of an image-based online questionnaire that we set to elucidate the role of sociodemographic affiliations regarding the perception of urban green areas. We also asked whether acceptability can be increased by the presence of additional structural elements (sculptures, benches) and "acceptance stripes", i.e., stripes regularly mowed only at the margins of a natural green space. Regarding structural elements, 40to 60-year-olds consistently rejected intensely maintained lawns and perceived a lawn as positive only in combination with a sculpture. A regularly mowed acceptance stripe resulted in a positive perception of natural meadows by people with an affinity for city life, classified based on their actual place of residence and/or their social dimension including aspects such as sense of place, familiarity, profession, and interests. Thus, decision-making processes of policy makers must be evaluated together with the urban population and should be assessed multidimensionally, i.e., by considering various criteria (e.g., ecological, social, and aesthetic aspects) in order to meet the requirements of residents and achieve an increase in biodiversity.
\end{abstract}

Keywords: acceptance stripes; biodiversity; conservation; lawn; meadow; multidimensional assessment; perception; questionnaire; survey; urban green space

\section{Introduction}

The value and contribution of natural urban green spaces to biodiversity and their ecological importance with respect to ecosystem services are well-known [1-7]. This green infrastructure has a variety of functions connected to the maintenance of basic ecological processes, properties, and resulting services [8-13], including positive climatic effects [3,8,14-20]. From a social point of view, urban green spaces offer facilities that can be used by city dwellers, e.g., as meeting points and places for relaxation and recreation $[8,9,21]$. In addition, they have multiple benefits (physiological and psychological) with respect to health and well-being (e.g., [7,8,22-30]).

Despite a general awareness of its value, urban green space is being forfeited over large parts of the world [1,31-34]. Because of the fast densification of numerous urban areas all over the planet, the remaining urban green spaces are under pressure [1,22,35-37]. Urban green spaces in cities contribute to increased biodiversity $[9,10,22,38-40]$, and the conservation of urban biodiversity can create multi-layered advantages for people and nature conservation alike [41,42]. However, current 
urban development contributes instead to the decline of biodiversity [22,43]. In the temperate zones, one special aspect of biodiversity loss in urban areas is anthropogenic manipulation involving the intense maintenance of lawns [9,44-46] and the planting of exotic plants [45-47]. Mown grassland, i.e., amenity grassland or lawn, is one of the most prevailing types of urban green space, particularly in temperate regions $[1,48,49]$. Demands have often been reported with respect to "the ecological, educational, aesthetic and sustainability benefits of urban meadows (i.e., naturalistic, unmown grassland with or without flowering forbs)" [1,50,51].

Indeed, many previous studies have shown an increase in urban biodiversity through the use of "extensive" meadows, i.e., meadows that are non-intensively mown (e.g., [44,52-60]). Since biodiversity is globally decreasing on several scales [6,61-65], concerns have been raised that this global decline will reduce the ability of ecosystems to provide human societies with a constant and endurable contribution of required goods and services [6,24,66-69]. Natural or near-natural ecosystems and habitats are needed to maintain certain ecological services (e.g., $[1,4,6,8,44,70]$ ) and sustainable conditions of health and well-being for future generations (e.g., [3,7,14,27,45,71-73]).

"'Landscape' means an area, as perceived by people, whose character is the result of the action and interaction of natural and/or human factors" [74]. The visual perception of landscape is a keystone that links humans with nature $[46,75]$. However, as the perception and aesthetic valuation of near-natural meadows in urban spaces vary strongly among citizens, the question arises regarding the ways in which such a subjective attitude can be quantified and made transparent and implementable in planning decisions [76]. Such processes should help to reconcile the well-being of urban populations and the promotion of biodiversity.

A study throughout Germany on nature awareness found that two out of three respondents voted for spaces in the city where nature can grow unrestrictedly, whereas 30 percent only appreciated such spaces to a limited extent or rejected such areas [77]. According to this study, natural sites in the city were mostly associated with parks and generally accessible public green spaces, which were discovered to be of major importance to the public, whereas trees and roadside greenery had a subordinate importance. These findings were supported by a later study, also conducted in Germany [75], which found that, for meadows and lawns, the factor "preservation" was rated lower than the factor "utilization". This also agreed with previous results of Bonnes et al. [78], who conducted two series of studies, one in the UK and one in Italy, showing that biodiversity was less important for respondents than the availability of urban green spaces [8]. Nevertheless, positive associations (e.g., aesthetics, restorative qualities, happiness) with biodiversity (e.g., $[1,7,8,22,24,26,75,77,79])$ in many studies (e.g., $[1,22,24,75,80-84]$ ) indicate an increasing appreciation of nature in European countries and a great predilection for variation, naturalness, and diversity in natural ecosystems [30]. Diversity has also been demonstrated to improve the aesthetic estimation of plant communities (e.g., [6,24,30,79,81,85-88]).

On the other hand, biodiversity is often not recognized or is estimated incorrectly because of the mismatch between the perceived and actual characteristics of biodiversity by laypersons $[8,24,41,89]$ as a result of poor knowledge [41] and the lack of a nuanced comprehension of naturalness within an urban context [8]. Indeed, biodiversity per se is frequently not appreciated (e.g., $[9,24,44,46,75,77,90-95]$ ), because the perception of nature by people is self-related and their evaluation of natural phenomena is tightly connected to selfish (practical and aesthetic) usage [75]. The topic of urban nature should encompass not only positive ecological aspects, but also people and their perception of nature conservation concepts. As the general populace perceives nature in ways different from those of ecologists $[8,24,41]$, we have explored key factors that possibly contribute to the positive perception of public green areas. If measures to increase and preserve biodiversity in urban areas are to be successfully implemented, the approval and support of the urban population needs to be sought $[41,96]$.

To evaluate urban nature in a pragmatic way, we chose an online survey in order to obtain the broadest possible diversity of opinions and a contemporary perception of urban green spaces by an urban population. As peoples' perception of natural scenery is known to be dependent on its overall setting [87,97-101], the goal of our survey was not to evaluate the general acceptance of extensively 
cultivated green spaces in cities, but to specify those measures that can be implemented to improve the perception of such spaces by the residents. Therefore, we focused on so-called "acceptance stripes" that can be easily created by mowing meadow areas only at their margins, leaving a central natural green space [3,102], but still achieving a well-kept appearance. Such transition zones of mown and unmown sectors are not only beneficial from an ecological perspective [3], but might also help to improve the understanding and acceptance of the human population towards extensively maintained meadows. Furthermore, public perception includes the effect of colors or locations and their settings, e.g., structural elements such as seating. Therefore, we also studied structural elements and their possible influence on potential increased acceptance of natural meadows. As the identification of key factors in the positive human perception of natural urban areas is of importance for conservation, we posed the following research questions:

(i) Can an acceptance stripe improve the perception or acceptance of natural meadows?

(ii) Can certain structural elements (e.g., seats or sculptures) generate positive perception regardless of the type of green space?

(iii) What influence does the socio-demographic affiliation of a citizen have on his or her acceptance behavior?

\section{Materials and Methods}

\subsection{Preparation and Implementation of the Questionnaire}

For data collection, an online survey was created as a quantitative instrument of analysis. This survey was created according to the requirements/standards of empirical social research [103]. It provided information on the perception of the surveyed urban citizens with regard to green spaces in the city of Tübingen, a university city in the center of Baden Württemberg (a federal state in the south of Germany).

Several image variants were created through the digital manipulation of parameters. The images were edited with "Adobe Photoshop CS 6" (Adobe, San Jose, CA, USA, 2012), i.e., the appropriate images of green space types were used digitally to create the respective scenarios. For instance, the cutout of a lawn image was used digitally to create an acceptance stripe around a meadow. Additionally, several images of a certain meadow type and occasionally various structural elements were used digitally to merge several images into one urban scenario.

The questionnaire was created and provided with the software "Unipark" [104]. The sequence of images related to the questions was randomized by the software, so that the appropriate images were visible in a random order for every participant. The questionnaire was distributed via the mailing list of the University of Tübingen, a list that comprises 37,895 students and employees from both academic and non-academic areas. Most participants were people from the academic university milieu and so were not fully representative of the urban population.

The data were collected between 31 March and 30 April 2016.

The participants were asked to answer spontaneously and to choose the scenario(s) that they found most appealing (Figures 1-5, and photo usage and details, see Appendix B). 


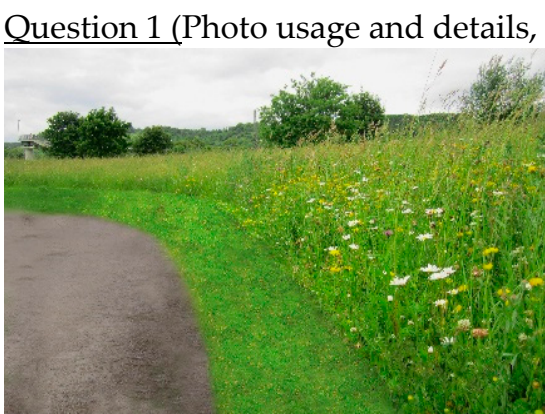

Natural meadow

with an acceptance stripe (1A)

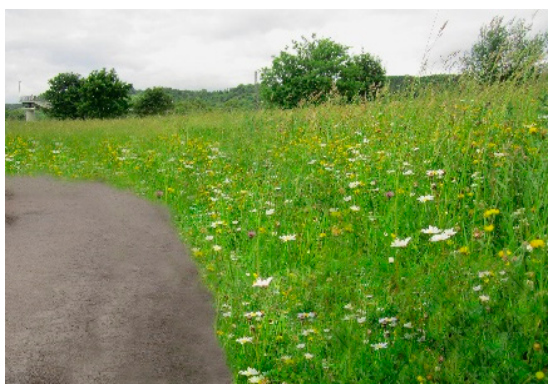

Natural meadow

(1B)

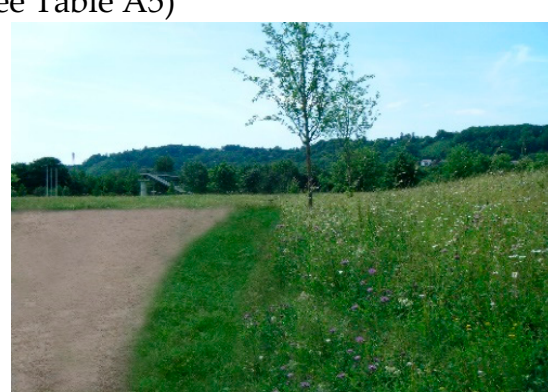

Natural meadow

with an acceptance stripe (1C)

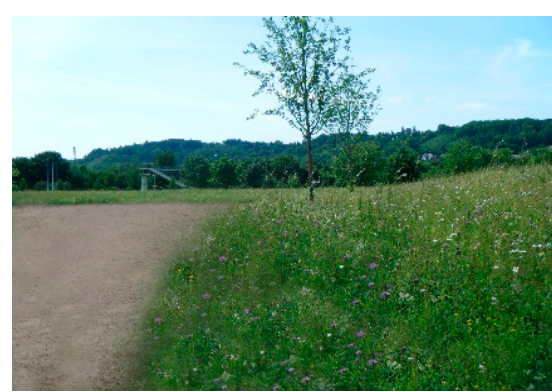

Natural meadow

(1D)

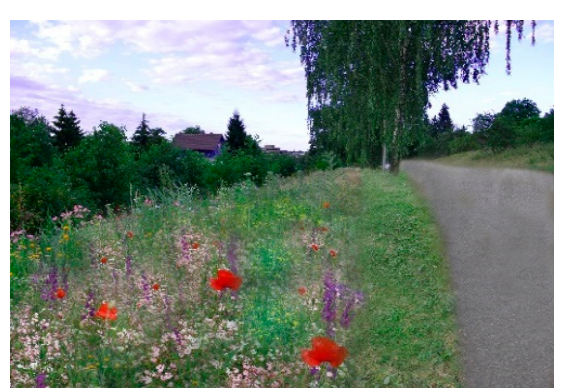

Unnatural green space with an acceptance stripe (1E)

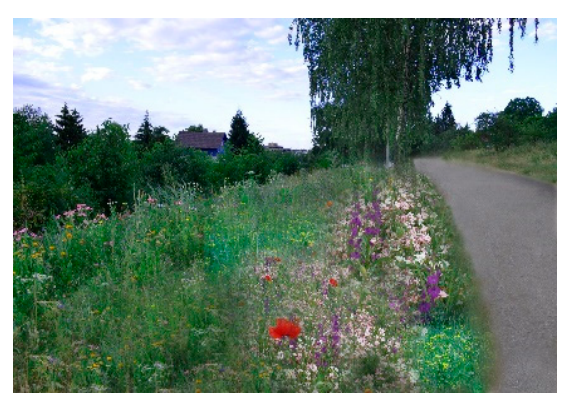

Unnatural green space

(1F)

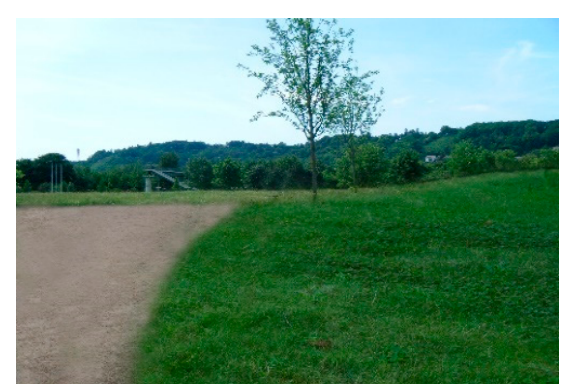

Lawn

(1G)

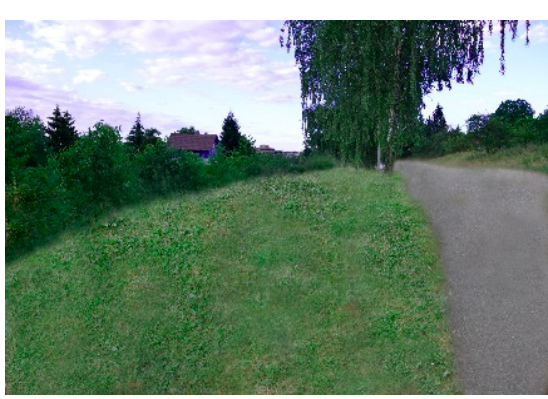

Lawn

Figure 1. The aim of Question 1 was to establish whether a preference existed among the surveyed participants for a certain type of green space. Alternatively, such a preference might depend on the presence of an acceptance stripe only. For further explanations, see text. 
Question 2.1 (Photo usage and details, see Table A6)

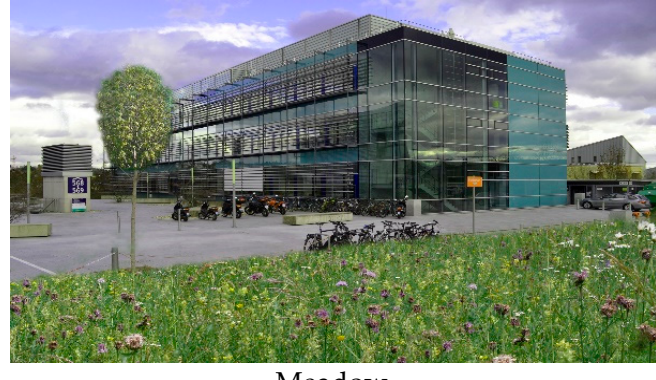

Meadow,

large forecourt (2.1A)

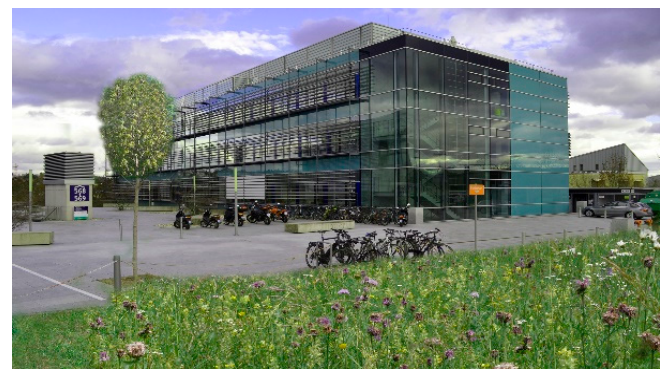

Meadow with an acceptance stripe, large forecourt (2.1D)

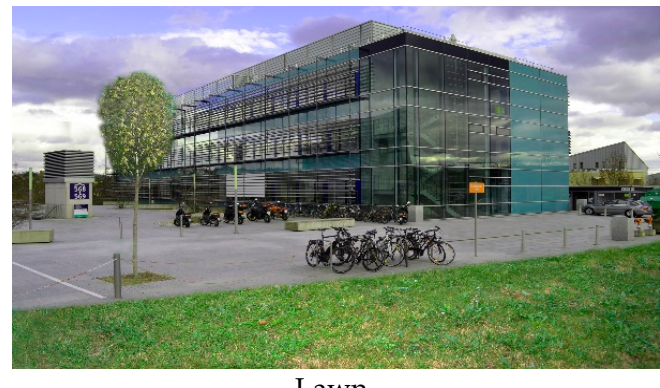

Lawn,

large forecourt $(2.1 \mathrm{G})$

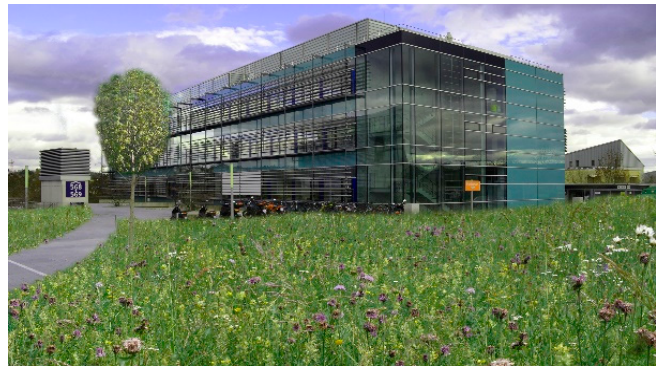

Meadow

small forecourt (2.1B)

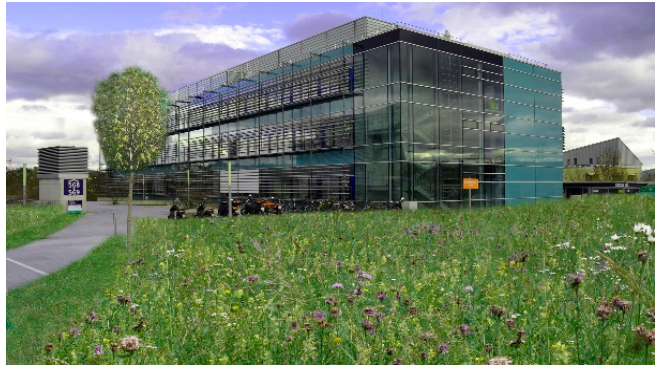

Meadow with an acceptance stripe, small forecourt (2.1E)

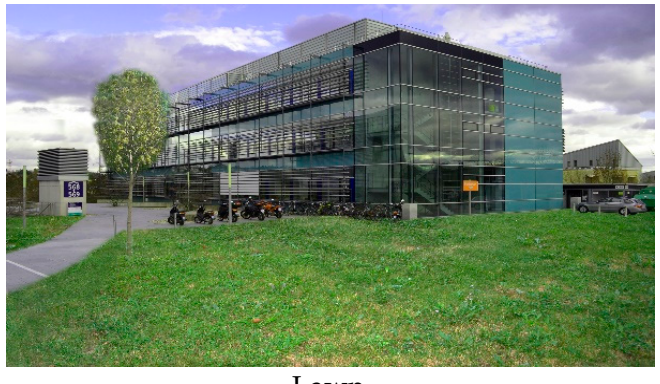

Lawn,

small forecourt $(2.1 \mathrm{H})$

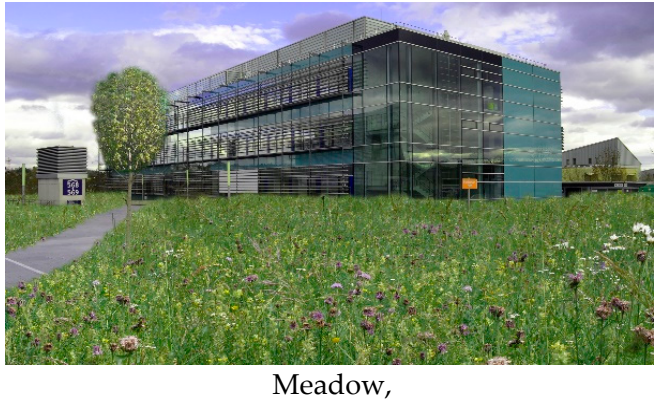

pathway $(2.1 \mathrm{C})$

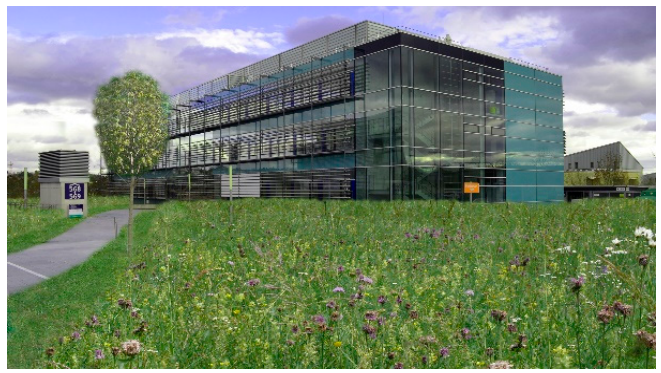

Meadow with an acceptance stripe, pathway $(2.1 \mathrm{~F})$

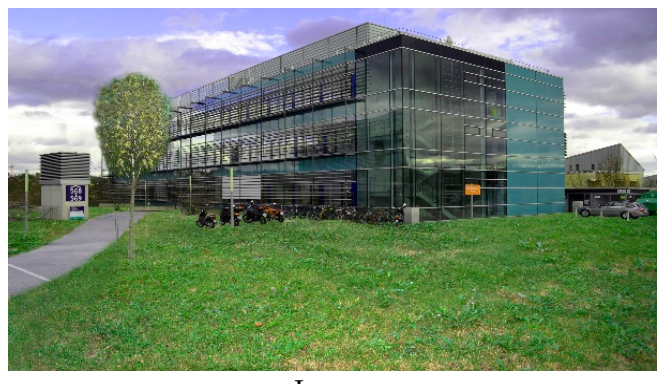

Lawn,

pathway (2.1I)

Figure 2. The aim of Question 2.1 was to establish the existence of a preference for a certain type of green space or a preference for the relative area of asphalt in relation to the green area. For further explanations, see text. 
Question 2.2 (Photo usage and details, see Table A7)

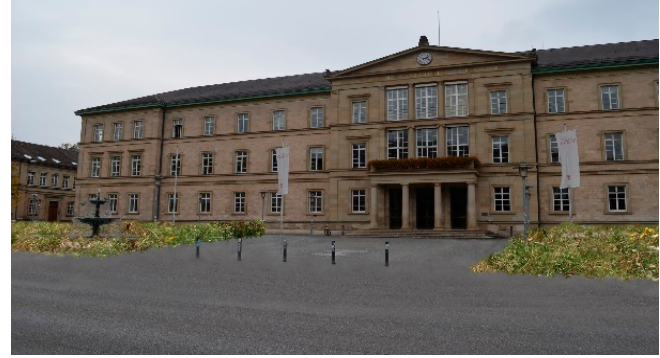

Meadow,

large forecourt (2.2A)

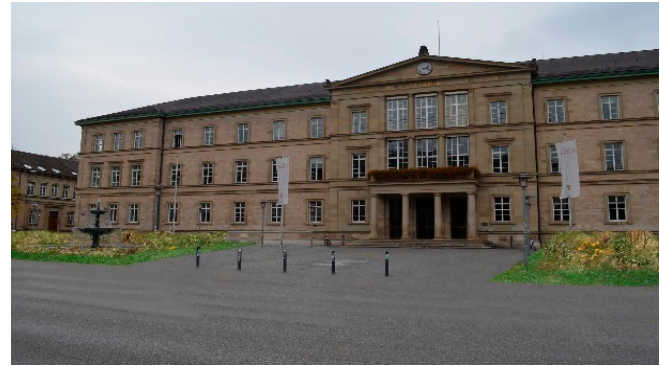

Meadow with an acceptance stripe, large forecourt (2.2D)

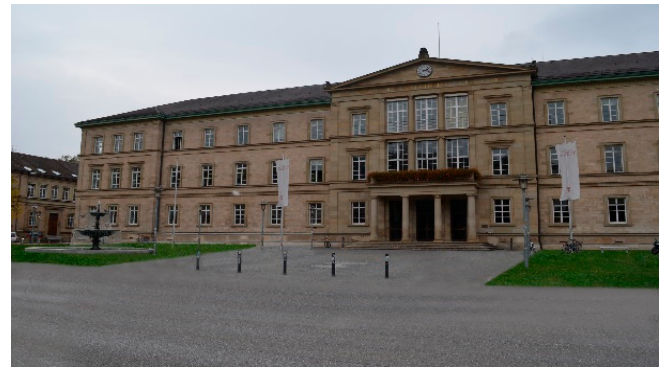

Lawn,

large forecourt (2.2G)

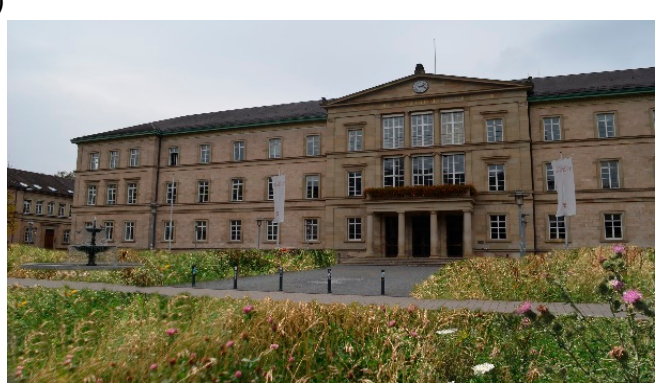

Meadow,

small forecourt (2.2B)

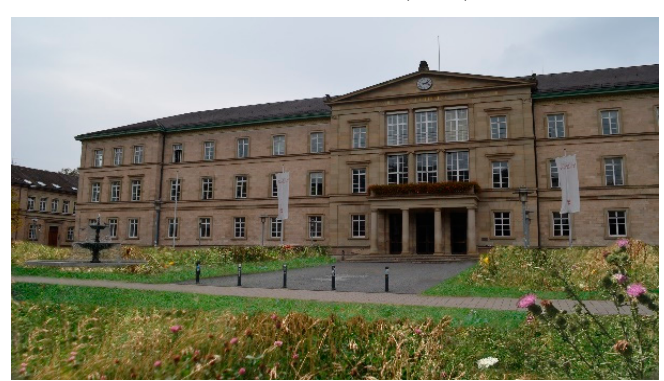

Meadow with an acceptance stripe, small forecourt (2.2E)

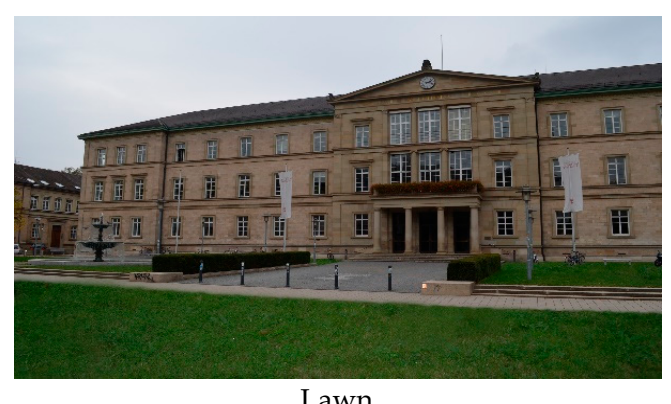

small forecourt $(2.2 \mathrm{H})$

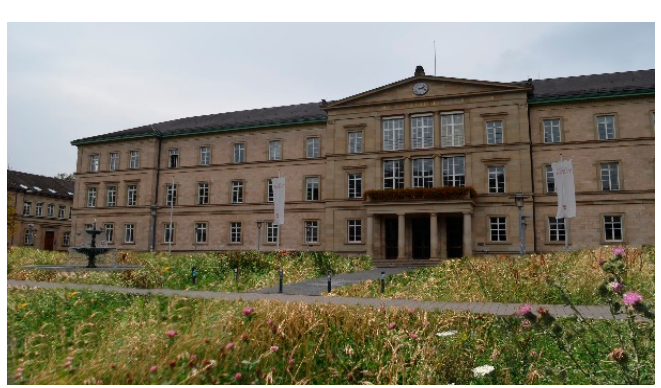

Meadow,

pathway $(2.2 \mathrm{C})$

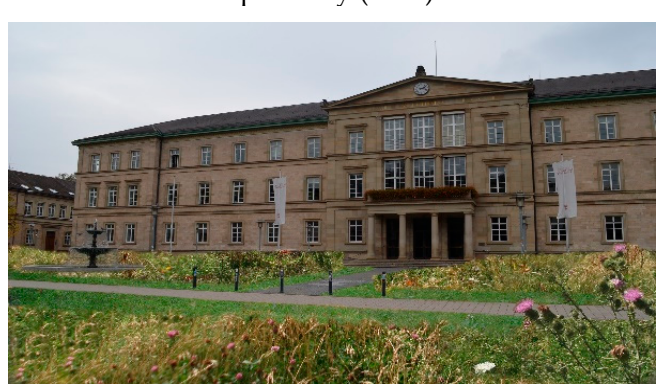

Meadow with an acceptance stripe, pathway $(2.2 \mathrm{~F})$

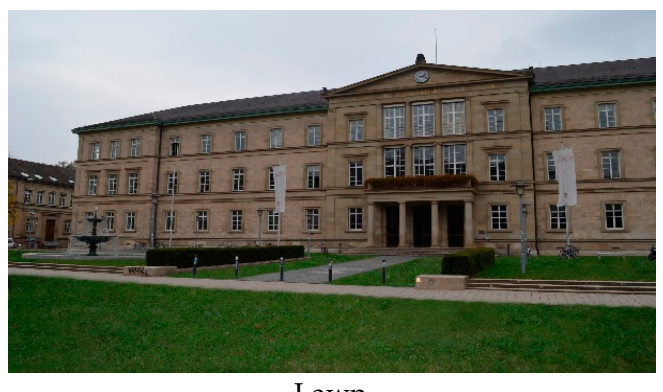

pathway (2.2I)

Figure 3. The aim of Question 2.2 was to establish the existence of a preference for a certain type of green space or a preference for the relative area of asphalt in relation to the green area. For further explanations, see text. 
Question 2.3 (Photo usage and details, see Table A8)

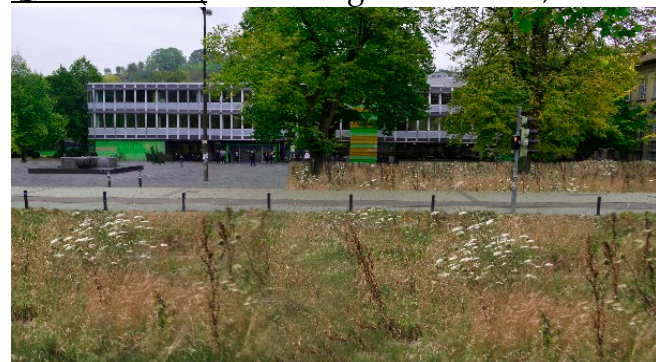

Meadow,

large forecourt (2.3A)

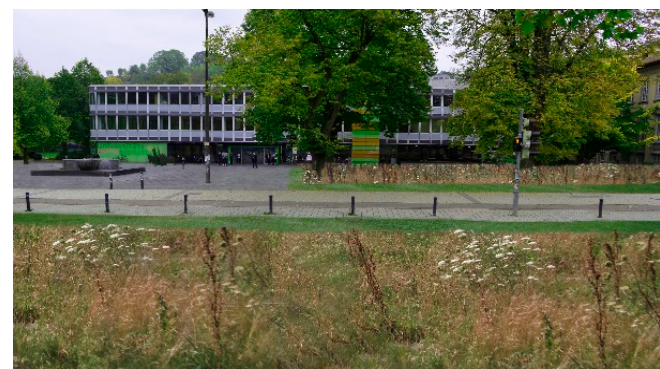

Meadow with an acceptance stripe, large forecourt (2.3D)

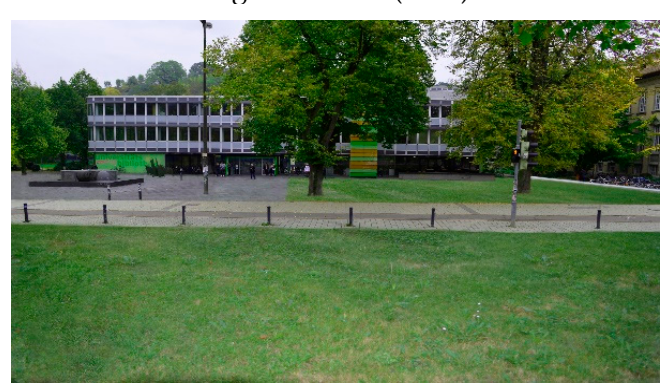

Lawn,

large forecourt (2.3G)

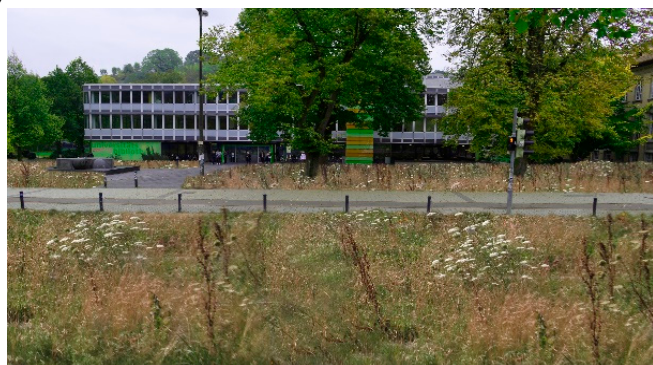

Meadow,

small forecourt (2.3B)

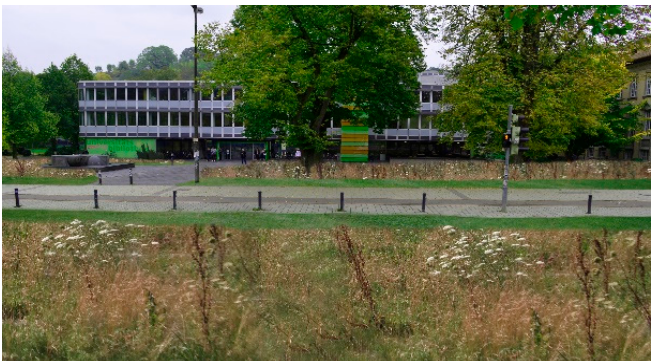

Meadow with an acceptance stripe, small forecourt (2.3E)

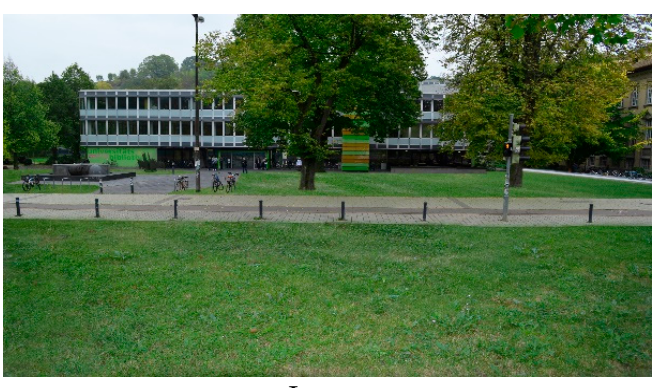

Lawn,

small forecourt $(2.3 \mathrm{H})$

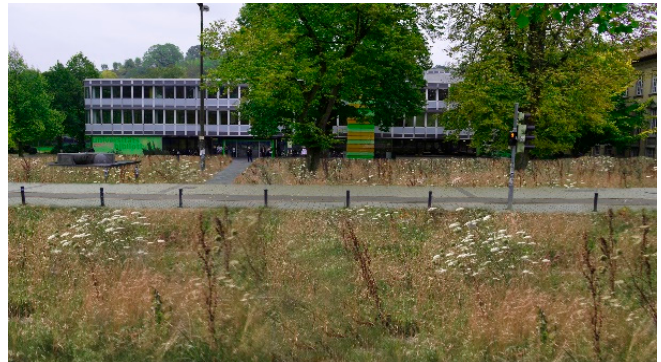

Meadow,

pathway $(2.3 \mathrm{C})$

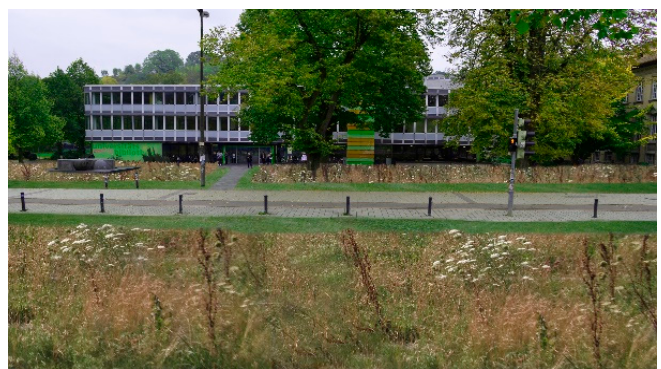

Meadow with an acceptance stripe, pathway $(2.3 \mathrm{~F})$

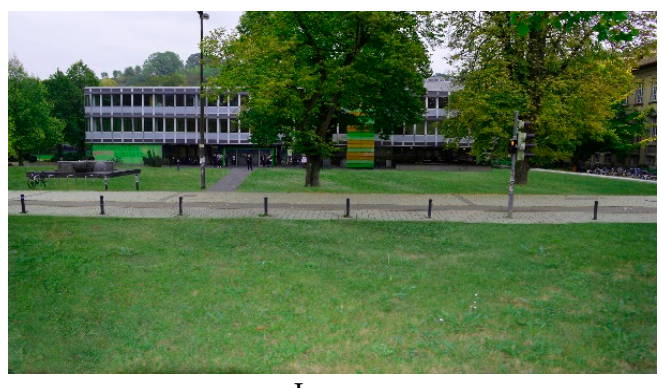

Lawn,

pathway $(2.3 \mathrm{I})$

Figure 4. The aim of Question 2.3 was to establish the existence of a preference for a certain type of green space or a preference for the relative area of asphalt in relation to the green area. For further explanations, see text. 


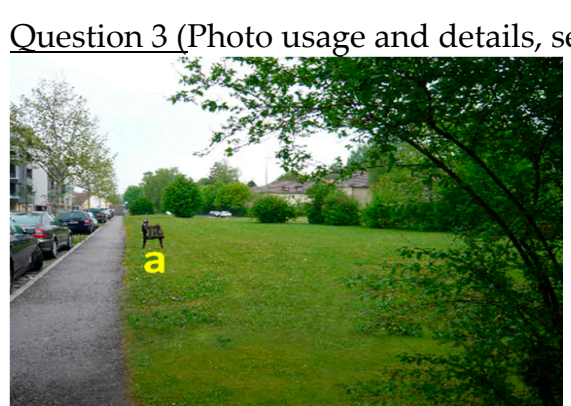

Lawn without trees Bench (3A)

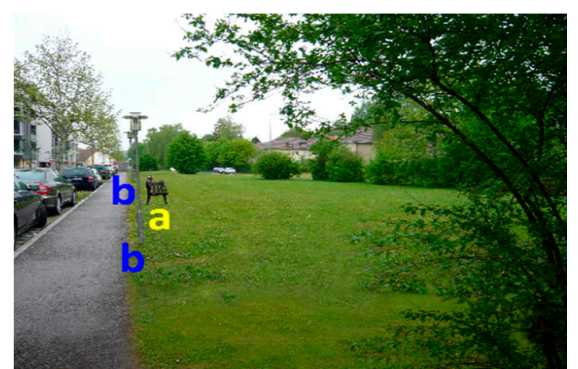

Lawn without trees Bench, lanterns (3B)

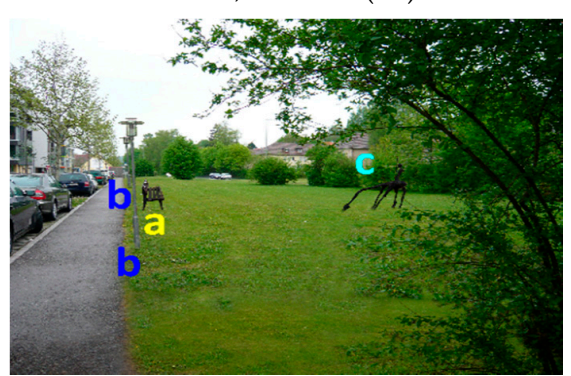

Lawn without trees Bench, lanterns, sculpture (3C)

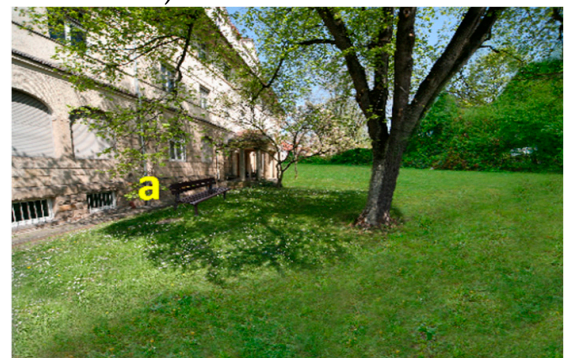

Lawn with trees Bench (3D)

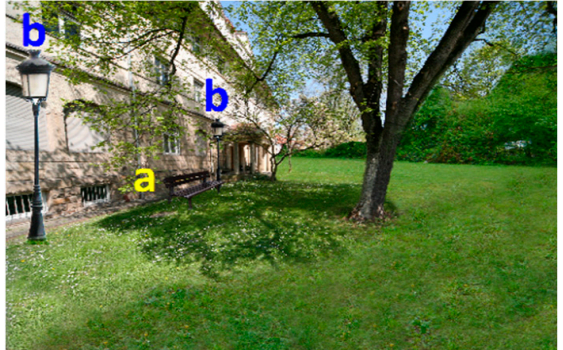

Lawn with trees Bench, lanterns * (3E)

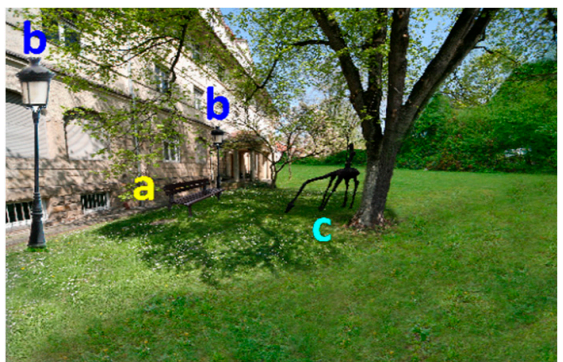

Lawn with trees

Bench, lanterns *, sculpture (3F)

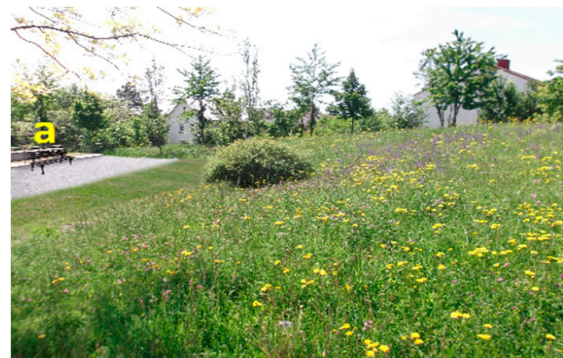

Meadow without trees Bench (3G)

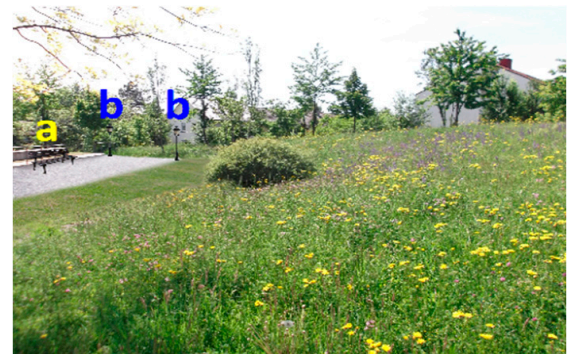

Meadow without trees Bench, lanterns * $(3 \mathrm{H})$

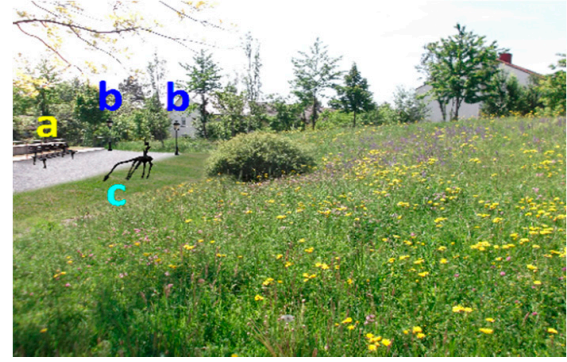

Meadow without trees Bench, lanterns *, sculpture (3I)

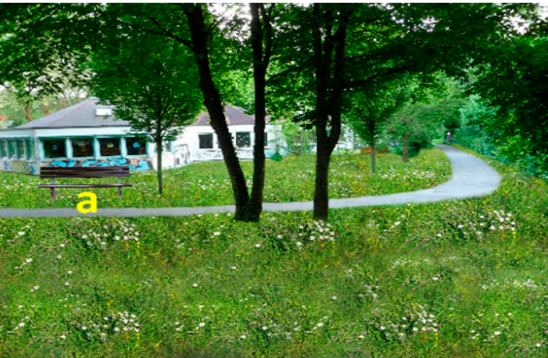

Meadow with trees Bench (3J)

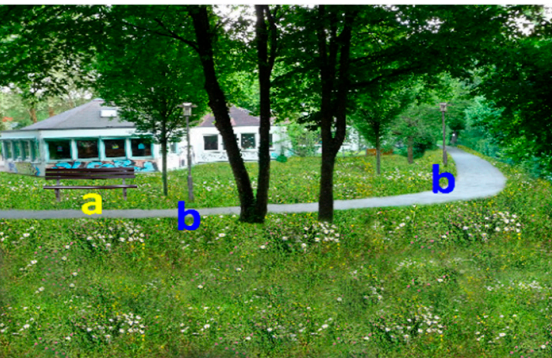

Meadow with trees Bench, lanterns (3K)

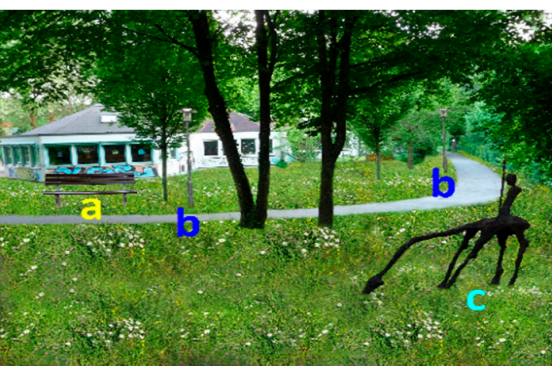

Meadow with trees

Bench, lanterns, sculpture (3L)

Figure 5. The aim of Question 3 was to establish possible preferences for a meadow or a lawn and the possible influence on the respective preference caused by the presence of structural elements. For further explanations, see text. ${ }^{*}$ ) FreeImages.com/sue anna joe (Artist's Member Name) [105]. 
All presented meadows, lawns, and scenarios in the questionnaire are located in the city of Tübingen and its surroundings, as familiarity has previously been found to strongly affect emotional reactions of respondents to the shown scenarios (e.g., [22,106-108]). The images of meadows, lawns, and unnatural green spaces were taken in the period from May to August over several years (2010, 2012, 2013, 2014, 2015) (Tables A5-A9). In order to maximize color saturation and to avoid any positive influences of sunshine on the perception of the respondents [109], all the photos were taken on overcast days.

The following scenarios were presented.

Natural versus unnatural green area, with or without an acceptance stripe, versus lawn area

To evaluate the perception of green spaces, the participants in our survey were confronted with various natural meadow concepts (Questions 1 and 2) versus an unnatural green space concept, i.e., a non-native seed mixture with especially bright flowers (Question 1); each of these concepts was presented with and without an acceptance stripe. In addition, pure lawns were presented that had scattered trees, hedges, and random artificial structures such as scooters, bikes, lanterns, wells, and a car (Questions 1 and 2).

Figure 1: The aim of the question associated with this figure was to establish whether a general preference existed for natural meadows, unnatural green spaces, or pure lawns among the surveyed participants and, in addition, to determine whether an acceptance stripe was necessary to create a positive perception for natural meadows. For this purpose, Question 1 included eight scenarios, i.e., (1) two natural meadows (A, B, C, D); (2) one unnatural green space consisting of a non-native seed mixture with especially bright flowers (E and F); (3) two pure lawns ( $\mathrm{G}$ and $\mathrm{H})$. Natural meadows and the unnatural green space were presented (i) with (A, C, E) versus (ii) without (B, D, F) an acceptance stripe in each case. The presentation of a pathway was chosen, because it conveys an urban character.

As up to two choices were possible for preferred scenarios, this arrangement helped to distinguish between preferences for a certain type of green area, i.e., (i) two decisions for a scenario with a natural meadow, (ii) with an unnatural meadow, or (iii) with a pure lawn. Within the scenarios of natural meadows, two decisions were possible for a scenario: (i) with an acceptance stripe versus (ii) without an acceptance stripe.

More versus less lawn area or natural green area, with or without an acceptance stripe

In order to evaluate the perception of green spaces within an urban scenario, three buildings (Questions 2.1,2.2, and 2.3) were photographed in the city of Tübingen.

Figures 2-4: The aim of the questions related to these figures was to establish whether a preference existed for a certain type of green space (i.e., meadow, meadow with an acceptance stripe, and pure lawn) within an urban scenario or whether the preference was influenced by the respective size of the forecourt, regardless of the green space type. For this purpose, Questions 2.1-2.3 included three different buildings, each being presented in nine different scenarios, i.e., three differently sized forecourts: (1) large (A, D, G), (2) small (B, E, H), and (3) with a pathway (C, F, I). The differently sized forecourts differed with respect to the relative area of asphalt in relation to the green area. Each of the above-mentioned scenarios presented the areas in three different ways, i.e., (i) with (D, E, F) versus (ii) without (A, B, C) an acceptance stripe, and (iii) as a pure lawn $(G, H, I)$.

As there were up to three possible choices, this arrangement helped to distinguish between preferences for a certain type of green area, i.e., (i) three decisions for a scenario with an acceptance stripe, (ii) without an acceptance stripe, or (iii) with a pure lawn. Alternatively, the preference might depend on the relative area of asphalt in relation to the green area, i.e., three decisions were again possible, namely, for a scenario (i) with a large forecourt, (ii) with a small forecourt, or (iii) with a pathway.

Natural green area versus lawn area and the influence of structural elements

The perception of the surveyed participants regarding structural elements placed on green spaces was also examined (Question 3). In this case, we presented only natural meadows without an acceptance stripe and pure lawns with scattered trees, hedges, and random artificial structures, such as 
cars. To examine the perception of structural elements (Question 3), images of two dissimilar benches as seating were presented. One bench was photographed from three different perspectives and the other one from only one perspective. Images of two dissimilar lanterns and one image of a sculpture were also used.

Figure 5: This question associated with this figure aimed at establishing possible preferences for a natural meadow (without acceptance stripe) or a lawn with scattered trees and hedges and, in particular, whether the presence of structural elements such as benches, lanterns, or sculptures had an influence on the preference or acceptance of the green space. To this end, question 3 showed twelve scenarios, i.e., (1) a lawn without a tree (A, B, C); (2) a lawn with a tree (D, E, F); (3) a meadow without a tree $(\mathrm{G}, \mathrm{H}, \mathrm{I}) ;(4)$ a meadow with a tree $(\mathrm{J}, \mathrm{K}, \mathrm{L})$. Each of the above-mentioned scenarios presented the areas in three different ways, i.e., (i) with (a) a bench only (A, D, G, J); (ii) with a bench, and (b) a combination of lanterns (B, E, H, K); (iii) with a bench and lanterns, and (c) a sculpture (C, F, I, L); (letters (a), (b), (c) refer to the letters used in Figure 5; they were not shown to the participants of the questionnaire). The different scenarios of Question 3 were examined as follows: 3.1 lawn without a tree versus meadow without a tree; 3.2 lawn with a tree versus meadow with a tree; 3.3 lawn with a tree versus lawn without a tree; 3.4 meadow with a tree versus meadow without a tree.

One decision had to be made for each of the above-mentioned combinations, i.e., a decision for the scenario (1) with a meadow or (2) with a lawn. Within these scenarios, a decision could be made for a scenario (i) with a bench only, (ii) with a bench and a combination of lanterns, or (iii) with a bench, lanterns, and a sculpture.

Our questionnaire was accompanied by a sociodemographic query that was aimed at correlating perception with possible social differences.

\subsection{Statistical Data Evaluation}

The questions represented by count data were evaluated on the basis of Chi-squared cross-tables [110]. Thereby, the chosen scenarios of each question were opposed to the sociodemographic data. For evaluating whether the number of answers for a given combination of a certain green space and respective sociodemographic data differed from the expected numbers, a Chi-squared test based on Pearson was used [110]. If the Chi-squared test was significant $(p<0.05)$, the standardized residuals were evaluated. Standardized residuals $>2.0$ or $<2.0$ were considered significant [110]. All statistics were performed with the software IBM SPSS Statistics; Version 23 (IBM, Armonk, NY, USA). If, in a particular question, the maximum number of possible choices was not exploited by a participant, the choices made were projected according to the maximum possible number of selections.

\section{Results}

The survey, which could be finished within 15 minutes by a participant, had a completion rate of $67 \%$ (out of 1367 participants). Participants were 31 years old on average and included $68.2 \%$ females, $31.6 \%$ males, and $0.2 \%$ who made no statement with respect to gender. Among the participants, $16.3 \%$ had children, and $67.1 \%$ of all subjects were students. Meanwhile, $53.7 \%$ of the respondents stated their commitment to nature conservation; $62.1 \%$ of the participants had an affinity for rural life, i.e., "country types", 35.9\% had an affinity for city life, i.e., "city types", and 2.0\% made no statement with respect to their self-perception.

The Roman numerals in all the presented tables have the following meaning: 
Age:

I.

II.

III.

IV.
$0-20$ years

20-40 years

40-60 years

60 years and older
Faculties:

I. Theology

II. Law

III. Medicine

IV. Humanities

V. Economic Sciences

VI. Social Sciences

VII. Natural Sciences

Under the heading "Student", the answer "No" means that the respondent was a research associate or non-academic staff member.

The following table presents, for each category of sociodemographic data, the total number of individuals within the category along with the corresponding percentage out of all participants registered by the software (Unipark) (Table 1 ).

Significant results (based on the standardized residual criterion as explained in Materials and Methods) are summarized in Tables 2-6, which present the number of choices for a certain green space made by the respective sociodemographic group (standardized residuals in brackets). 
Table 1. Categories with regard to sociodemographic data and number of assigned survey participants.

\begin{tabular}{|c|c|c|c|c|c|c|c|c|c|c|c|c|c|c|c|c|c|c|c|c|c|c|c|c|}
\hline & \multicolumn{4}{|c|}{ Age } & \multicolumn{3}{|c|}{ Gender } & \multicolumn{2}{|c|}{ Has Children } & \multicolumn{2}{|c|}{ Student } & \multicolumn{7}{|c|}{ Faculty } & \multicolumn{3}{|c|}{ Commitment to Conservation } & \multicolumn{3}{|c|}{ Self-Perception } \\
\hline & I. & II. & III. & IV. & Male & Female & N/A & Yes & No & Yes & No & I. & II. & III. & IV. & V. & VI. & VII. & Yes & No & N/A & Country Type & City Type & N/A \\
\hline Tota & 73 & 665 & 151 & 27 & 289 & 25 & 2 & 1 & 76 & 6 & 30 & 21 & 19 & 63 & 17 & 26 & 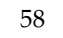 & 25 & 49 & 41 & 6 & 56 & 327 & 18 \\
\hline$\%$ & 8.0 & 72.6 & 16.5 & 2.9 & 31.6 & 68.2 & 0.2 & 16.3 & 83.7 & 67.1 & 32.9 & 3.4 & 3.1 & 10.3 & 28.3 & 4.2 & 9.5 & 41.2 & 53.7 & 45.6 & 0.7 & 62.1 & 35.9 & 2.0 \\
\hline
\end{tabular}


Table 2. Question 1 compared natural early summer meadows with unnatural green spaces (1E and $1 \mathrm{~F})$ and lawns (1G and $1 \mathrm{H})$. The meadows and unnatural green spaces were illustrated with (1E) and without $(1 \mathrm{~F})$ an acceptance stripe. The table presents the number of choices for a certain green space by the respective sociodemographic group (standardized residuals in brackets). Whereas a positive residual indicates that the scenario was appreciated by the relevant demographic group (bold type), a negative residual indicates that the scenario was disliked (normal typeface). Only significant cases are listed.

\begin{tabular}{|c|c|c|c|c|c|c|c|c|}
\hline & \multicolumn{3}{|c|}{ Gender Student } & \multicolumn{2}{|c|}{ Faculty } & \multirow[b]{2}{*}{ VII. } & \multicolumn{2}{|c|}{ Commitment to Conservation } \\
\hline & Male & No & II. & III. & VI. & & Yes & No \\
\hline $\begin{array}{c}\text { Unnatural Green Space } \\
\text { with an Acceptance Stripe (1E) }\end{array}$ & & $\begin{array}{c}7 \\
(-2.5)\end{array}$ & & & & & & \\
\hline Unnatural Green Space (1F) & & & & & $\begin{array}{c}30 \\
(2.1)\end{array}$ & & & \\
\hline Lawn (1G) & & & & $\begin{array}{l}10 \\
(2.4)\end{array}$ & & $\begin{array}{l}10 \\
(-2.1)\end{array}$ & & \\
\hline Lawn (1H) & $\begin{array}{c}29 \\
(3.0)\end{array}$ & & $\begin{array}{c}4 \\
(2.2)\end{array}$ & & & & $\begin{array}{c}15 \\
(-2.5)\end{array}$ & $\begin{array}{c}37 \\
(2.7)\end{array}$ \\
\hline
\end{tabular}

Table 3. Question 2.1 compared natural early summer meadows (2.1B and 2.1F) with lawns (2.1G, $2.1 \mathrm{H}$, and $2.1 \mathrm{I})$. The meadows were illustrated with $(2.1 \mathrm{~F})$ and without $(2.1 \mathrm{~B})$ an acceptance stripe. All green spaces were presented with variation in the degree of overgrowth: large forecourt $(2.1 \mathrm{G})$; small forecourt $(2.1 \mathrm{~B}$ and $2.1 \mathrm{H})$; with a pathway $(2.1 \mathrm{~F}$ and $2.1 \mathrm{I})$. The table presents the number of choices for a certain green space by the respective sociodemographic group (standardized residuals in brackets). Whereas a positive residual indicates that the scenario was appreciated by the relevant demographic group (bold type), a negative residual indicates that the scenario was disliked (normal typeface). Only significant cases are listed.

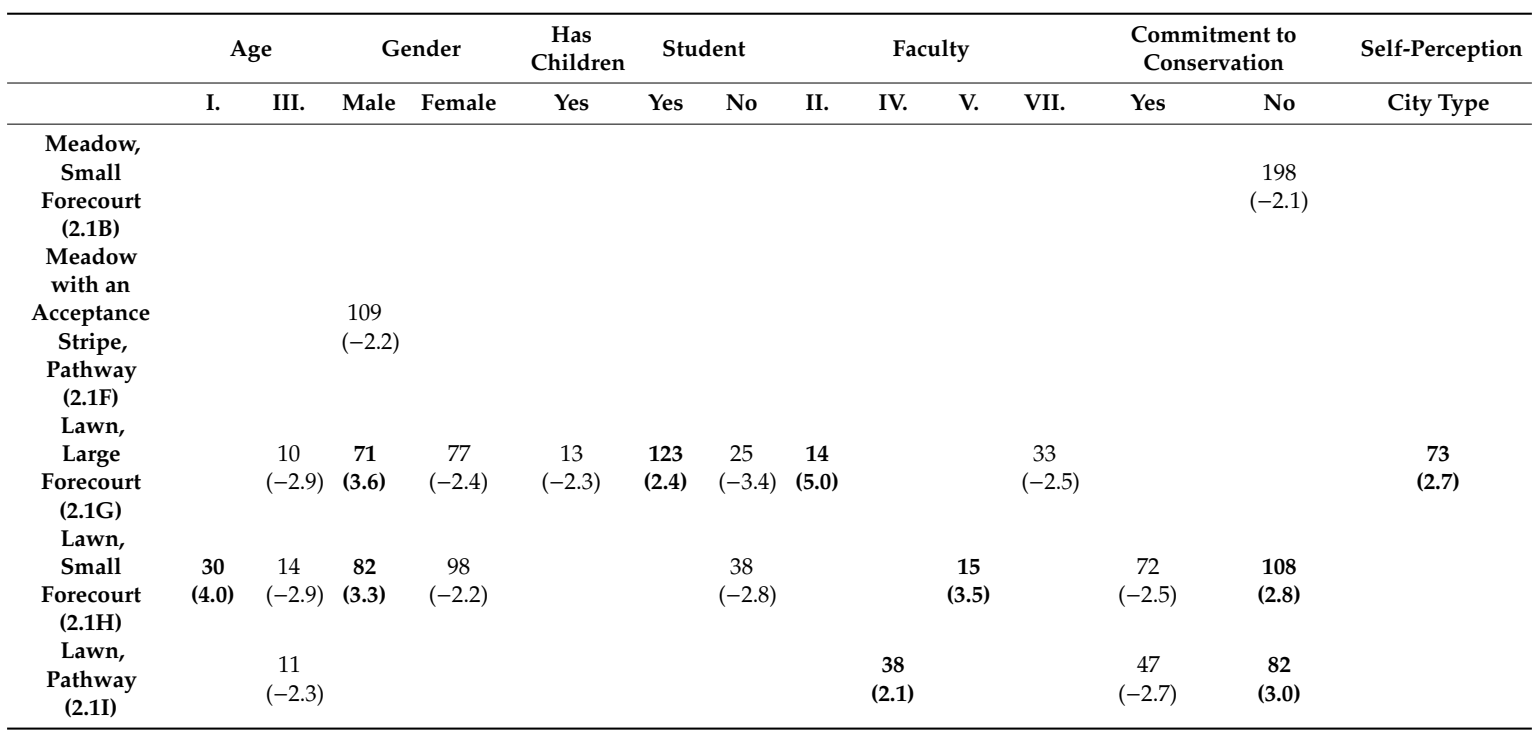


Table 4. Question 2.2 compared natural late summer meadows (2.2A, 2.2B, 2.2C, 2.2D, 2.2E, and 2.2F) with lawns (2.2G, 2.2H, and 2.2I). The meadows were illustrated with $(2.2 \mathrm{D}, 2.2 \mathrm{E}$, and $2.2 \mathrm{~F})$ and without $(2.2 \mathrm{~A}, 2.2 \mathrm{~B}$, and $2.2 \mathrm{C})$ an acceptance stripe. All green spaces were presented with variation in the degree of overgrowth: large forecourt (2.2A, 2.2D, and 2.2G); small forecourt (2.2B, 2.2E, and 2.2H); with a pathway $(2.2 \mathrm{C}, 2.2 \mathrm{~F}$, and 2.2I). The table presents the number of choices for a certain green space by the respective sociodemographic group (standardized residuals in brackets). Whereas a positive residual indicates that the scenario was appreciated by the relevant demographic group (bold type), a negative residual indicates that the scenario was disliked (normal typeface). Only significant cases are listed.

\begin{tabular}{|c|c|c|c|c|c|c|c|c|c|c|c|c|}
\hline & \multirow{2}{*}{$\begin{array}{c}\text { Age } \\
\text { III. }\end{array}$} & \multirow{2}{*}{$\begin{array}{c}\begin{array}{c}\text { Has } \\
\text { Children }\end{array} \\
\text { Yes }\end{array}$} & \multicolumn{2}{|c|}{ Student } & \multicolumn{4}{|c|}{ Faculty } & \multicolumn{2}{|c|}{ Commitment to Conservation } & \multicolumn{2}{|c|}{ Self-Perception } \\
\hline & & & Yes & No & I. & II. & III. & VI. & Yes & No & Country Type & City Type \\
\hline $\begin{array}{c}\text { Meadow, } \\
\text { Large Forecourt (2.2A) }\end{array}$ & & & & & & $\begin{array}{c}4 \\
(3.1)\end{array}$ & & & & & & \\
\hline Meadow, & & & & 82 & & & & & 127 & 63 & & \\
\hline Small Forecourt (2.2B) & & & & (2.4) & & & & & (2.4) & $(-2.6)$ & & \\
\hline Meadow, & 66 & 57 & 126 & 105 & & & & & $160(3.2)$ & 71 & & \\
\hline $\begin{array}{c}\text { Pathway (2.2C) } \\
\text { Meadow with an Acceptance Stripe, } \\
\text { Large Forecourt (2.2D) }\end{array}$ & (4.5) & $\begin{array}{c}(3.1) \\
6 \\
(-2.3)\end{array}$ & & $(3.3)$ & & & & & & & & \\
\hline $\begin{array}{c}\text { Meadow with an Acceptance Stripe, } \\
\text { Small Forecourt (2.2E) }\end{array}$ & & & & & $\begin{array}{c}17 \\
(2.3)\end{array}$ & & & & & & & \\
\hline $\begin{array}{c}\text { Meadow with an Acceptance Stripe, } \\
\text { Pathway (2.2F) }\end{array}$ & & & & & & & & & $\begin{array}{l}336 \\
(3.1)\end{array}$ & $\begin{array}{c}189 \\
(-3.3)\end{array}$ & & \\
\hline $\begin{array}{c}\text { Lawn, } \\
\text { Large Forecourt (2.2G) }\end{array}$ & & & & & & $\begin{array}{c}8 \\
(2.8)\end{array}$ & & & $\begin{array}{c}56 \\
(-2.4)\end{array}$ & $\begin{array}{c}86 \\
(2.5)\end{array}$ & $\begin{array}{c}68 \\
(-2.2)\end{array}$ & $\begin{array}{c}68 \\
(2.3)\end{array}$ \\
\hline $\begin{array}{l}\text { Lawn, } \\
\text { Small Forecourt (2.2H) }\end{array}$ & & & & & & & $\begin{array}{c}49 \\
(2.7)\end{array}$ & $\begin{array}{c}19 \\
(-2.1)\end{array}$ & $\begin{array}{c}219 \\
(-2.5)\end{array}$ & $\begin{array}{r}260 \\
(2.7)\end{array}$ & & \\
\hline $\begin{array}{c}\text { Lawn, } \\
\text { Pathway (2.2I) }\end{array}$ & $\begin{array}{c}72 \\
(-3.1)\end{array}$ & & & $\begin{array}{c}165 \\
(-2.8)\end{array}$ & & & & & $\begin{array}{c}294 \\
(-2.2)\end{array}$ & $\begin{array}{l}324 \\
(2.4)\end{array}$ & & \\
\hline
\end{tabular}


Table 5. Question 2.3 compared natural late summer meadows (2.3A, 2.3B, 2.3C, 2.3D, 2.3E, and 2.3F) with lawns (2.3G, 2.3H, and 2.3I). The meadows were illustrated with $(2.3 \mathrm{D}, 2.3 \mathrm{E}$, and $2.3 \mathrm{~F})$ and without $(2.3 \mathrm{~A}, 2.3 \mathrm{~B}$, and $2.3 \mathrm{C})$ an acceptance stripe. All green spaces were presented with variation in the degree of overgrowth: large forecourt (2.3A, 2.3D, and 2.3G); small forecourt (2.3B, 2.3E, and 2.3H); with a pathway (2.3C, 2.3F, and 2.3I). The table presents the number of choices for a certain green space by the respective sociodemographic group (standardized residuals in brackets). Whereas a positive residual indicates that the scenario was appreciated by the relevant demographic group (bold type), a negative residual indicates that the scenario was disliked (normal typeface). Only significant cases are listed.

\begin{tabular}{|c|c|c|c|c|c|c|c|c|c|c|c|c|c|c|c|c|}
\hline & \multicolumn{3}{|c|}{ Age } & \multicolumn{2}{|c|}{ Gender } & \multirow{2}{*}{$\begin{array}{c}\text { Has Children } \\
\text { Yes }\end{array}$} & \multicolumn{2}{|c|}{ Student } & \multicolumn{5}{|c|}{ Faculty } & \multicolumn{2}{|c|}{ Commitment to Conservation } & \multirow{2}{*}{$\begin{array}{c}\text { Self-Perception } \\
\text { City Type }\end{array}$} \\
\hline & II. & III. & IV. & Male & Female & & Yes & No & II. & III. & V. & VI. & VII. & Yes & No & \\
\hline Meadow, & & & & & & & & & & & & & & 100 & 49 & \\
\hline Large Forecourt (2.3A) & & & & & & & & & & & & & & $(2.2)$ & $(-2.3)$ & \\
\hline Meadow, & 109 & 60 & 13 & & & 55 & 99 & 94 & & & & & & & & 49 \\
\hline Small Forecourt (2.3B) & $(-2.7)$ & (4.9) & (2.9) & & & (4.2) & $(-2.7)$ & (3.8) & & & & & & & & $(-2.5)$ \\
\hline Meadow, & & 47 & 13 & 84 & & & & 85 & & 5 & & & 67 & 141 & 66 & \\
\hline Pathway (2.3C) & & (2.2) & (2.7) & (2.3) & & & & (2.1) & & $(-2.2)$ & & & (2.3) & $(2.8)$ & $(-3.0)$ & \\
\hline Meadow with an Acceptance & & & & & & & & & & & & & & & & \\
\hline $\begin{array}{c}\text { Stripe, } \\
\text { Large Forecourt (2.3D) }\end{array}$ & & $\begin{array}{c}44 \\
(2.4)\end{array}$ & & & & & & & & & & & & & & \\
\hline Meadow with an Acceptance & & & & & & & & & & & & & & & & \\
\hline $\begin{array}{c}\text { Stripe, } \\
\text { Small Forecourt (2.3E) }\end{array}$ & & & $\begin{array}{c}13 \\
(2.2)\end{array}$ & & & & & & & & $\begin{array}{l}1 \\
(-2.1)\end{array}$ & & $\begin{array}{l}74 \\
(2.1)\end{array}$ & $\begin{array}{l}148 \\
(2.1)\end{array}$ & $\begin{array}{c}84 \\
(-2.2)\end{array}$ & $\begin{array}{l}103 \\
(2.1)\end{array}$ \\
\hline $\begin{array}{c}\text { Meadow with an Acceptance } \\
\text { Stripe, } \\
\text { Pathway (2.3F) }\end{array}$ & & & & & & & & & & & & & & & $\begin{array}{c}96 \\
(-2.1)\end{array}$ & \\
\hline $\begin{array}{l}\text { Lawn, } \\
\text { Large Forecourt (2.3G) }\end{array}$ & & $\begin{array}{c}46 \\
(-2.1)\end{array}$ & & $\begin{array}{c}156 \\
(3.4)\end{array}$ & $\begin{array}{c}218 \\
(-2.4)\end{array}$ & $\begin{array}{c}45 \\
(-2.1)\end{array}$ & $\begin{array}{l}290 \\
(2.4)\end{array}$ & $\begin{array}{l}86 \\
(-3.4)\end{array}$ & $\begin{array}{l}16 \\
(2.3)\end{array}$ & & & $\begin{array}{l}15 \\
(-2.4)\end{array}$ & & $\begin{array}{c}156 \\
(-3.1)\end{array}$ & $\begin{array}{c}214 \\
(3.4)\end{array}$ & \\
\hline Lawn, & & & 6 & 171 & & & & & & & & & & 302 & 338 & \\
\hline Small Forecourt $(2.3 \mathrm{H})$ & & & $(-3.1)$ & $(-2.3)$ & & & & & & & & & & $(-2.4)$ & (2.5) & \\
\hline $\begin{array}{l}\text { Lawn, } \\
\text { Pathway (23I) }\end{array}$ & & $\begin{array}{c}40 \\
(-48)\end{array}$ & & & & & & & & & & & 122 & $\begin{array}{c}231 \\
(-24)\end{array}$ & $\begin{array}{r}269 \\
(25)\end{array}$ & \\
\hline Pathway (2.3I) & & $(-4.8)$ & & & & & & & & & & & $(-2.2)$ & $(-2.4)$ & (2.5) & \\
\hline
\end{tabular}


Table 6. Question 3 compared natural early summer meadows with (3J and 3L) and without (3G and 3I) trees, and lawns with (3E and 3F) and without (3A, 3B, and 3C) trees. The influence of certain structural elements on the acceptance regarding natural green spaces (without an acceptance stripe) and lawns was established here, i.e., bench placed on a lawn (3A) or a meadow (3G and 3J); bench and lanterns placed on a lawn (3B and 3E) or a meadow; bench, lanterns and sculpture placed on a lawn (3C and 3F) or a meadow (3I and 3L). The table presents the number of choices for a certain green space by the respective sociodemographic group (standardized residuals in brackets). Whereas a positive residual indicates that the scenario was appreciated by the relevant demographic group (bold type), a negative residual indicates that the scenario was disliked (normal typeface). This question was divided into four sub-questions; each image was presented twice as two separate questions: the results of (i) the first sub-question are shown in the upper line; the results of (ii) the second sub-question in the lower line. Only significant cases are listed.

\begin{tabular}{|c|c|c|c|c|c|c|c|c|c|c|c|}
\hline & & Age & & Gender & $\begin{array}{c}\text { Has } \\
\text { Children }\end{array}$ & & lent & & & & \\
\hline & I. & II. & III. & Male & Yes & Yes & No & I. & II. & IV. & $\mathrm{V}$. \\
\hline $\begin{array}{c}\text { Lawn without Trees } \\
\text { Bench (3A) }\end{array}$ & ii: 10 (3.4) & & & & & & & & & & i: $5(2.7)$ \\
\hline Lawn without Trees & & & i: $1(-2.4)$ & & & & i: $5(-2.5)$ & ii: 5 (3.8) & i: 4 (2.5) & & \\
\hline $\begin{array}{l}\text { Bench, Lanterns (3B) } \\
\text { Lawn without Trees }\end{array}$ & & & 11: $1(-2.1)$ & i: $21(3.0)$ & & & & & & & \\
\hline Bench, Lanterns, Sculpture (3C) & & & & ii: $9(2.2)$ & & & & & ii: 2 (3.5) & i: $15(3.0)$ & \\
\hline $\begin{array}{l}\text { Lawn with Trees } \\
\text { Bench, Lanterns (3E) }\end{array}$ & & & i: $21(-2.5)$ & ii: $86(-2.3)$ & i: $23(-2.1)$ & & & & & & \\
\hline $\begin{array}{l}\text { Meadow without Trees } \\
\text { Bench (3G) }\end{array}$ & ii: $14(-2.1)$ & & & & & & & & & & \\
\hline Meadow without Trees & & & i: 46 (2.8) & & & & & & & & \\
\hline Bench, Lanterns, Sculpture (3I) & & & ii: $23(2.8)$ & & & & & & & & \\
\hline $\begin{array}{c}\text { Meadow with Trees } \\
\text { Bench (3J) }\end{array}$ & & & ii: $9(-2.1)$ & & & & & & & & \\
\hline $\begin{array}{l}\text { Meadow with Trees } \\
\text { Bench, Lanterns, Sculpture (3L) }\end{array}$ & & i: $41(-2.2)$ & $\begin{array}{l}\text { i: } 30(4.7) \\
\text { ii: } 16(3.1)\end{array}$ & & i: $23(2.8)$ & i: $32(-2.9)$ & $\begin{array}{l}\text { i: } 47(4.1) \\
\text { ii: } 25(2.5)\end{array}$ & & & & \\
\hline
\end{tabular}


In the Appendix A we present all the significant lawn areas (Table A1) and all the significant meadow areas (Table A2) with respect to age, gender, people with children, students, and non-students. Furthermore, we present all the significant lawn areas (Table A3) and all the significant meadow areas (Table A4) with respect to faculties, commitment to nature conservation, and peoples' self-perception.

\section{Discussion}

The overall goal of this study was to specify measurements that could be implemented to improve the perception of extensively cultivated green spaces by the urban population. From the more practically relevant view of urban planning, our survey aimed to determine whether (1) an acceptance stripe could improve the perception or acceptance of natural meadows and whether (2) certain structural elements could generate positive perception regardless of the type of green space. For these purposes, we presented digitally manipulated urban landscape scenes to participants of a questionnaire and related the responses to their sociodemographic data.

Generally, the encompassing value and meaning of a landscape for human beings depends on perception [111] as the result of an ongoing subconscious mental interpretation of the characteristics of a landscape, e.g., biodiversity, stage of development of the green space, total vegetation coverage [90], and their effects on and interaction with so-called human factors [79,111-113]. These human factors include the biological, social, cultural and personal dimensions on which the perception of the environment is assessed [111,114]. Home et al. [115] showed that urban green spaces are mainly assessed on biological and social dimensions [111]. Well-developed theories about the universal (biological-evolutionary) dimension refer to habitat theories that postulate a common neurophysiological basis of the experience of landscape leading to a generally similar impression of structures and elements by humans on a global scale [101,111,114,116-121]. Whereas preferences of the biological dimension are inherited, the social dimension (including aspects such as sense of place, familiarity, profession, and interests) must also be considered [111]. Certain structures and elements of a landscape seem to be experienced in a similar way within cultures and social groups, especially if the landscape is assessed on a larger scale $[111,116,122-124]$. The smaller this scale, the more differentiated the different social groups are with respect to their landscape perception [111].

A landscape can have quite diverse values and meanings (e.g., recreation, utilization, or economic area) for different social groups depending on their social background [111]. Therefore, social groups have to be properly identified in questionnaires concerning landscape perception in order to attain a more complete picture of their respective green space use. Since the perception and utility of nature depend at least as much on lifestyle and value orientation [77], such as pro-environmental attitudes $[1,8,78,125]$, as they do on social background, demographic data should be extended by the evaluation of milieu affiliation [77]. Thus, a more differentiated explanation of individual attitudes, behavioral patterns, and connections in relation to nature can be attained [77].

In the following, we discuss our results with respect to the socio-demographic groups. This is followed by the consideration of the overall setting, with an assessment of the preference for green spaces in the context of buildings and structural elements. Moreover, we examine the multidimensionality of assessing landscapes and the viewing perspective (angle, distance) from which a site is perceived. Our major practical results concern the preference for green spaces in the context of the presence or absence of an acceptance stripe and of structural elements such as benches or sculptures, enabling us finally to suggest practical measures for urban planners and green space managers.

\subsection{Peoples' Self-Perception}

The classification of the participants as "country" versus "city" types is based on their background with respect to their actual place of residence (possibly connected to cultural influences) and/or their social dimension. Since both geographic and cultural contexts have an influence on landscape preference [22,126-128], both should be considered in the context of green space design. 
In our study, lawn scenarios were preferred by "city types", a result possibly arising because lawns are one of the most prevailing types of urban green spaces in temperate regions $[1,24,46,48,49,94,129,130]$. However, consideration of the social dimension is important in order to determine the significant reason(s) for lawn preference, e.g., restorative relaxation effect (e.g., [24]), aesthetics (e.g., [75]), and/or utilization. For example, even if an individual appreciates nature, his or her interest in utilization might overweigh all other aspects [75]. Thus, although lawns might not be valued positively, they may answer other functional demands [8]. In other cases in which the relevant space is not required for utilization, and in which nature is valued positively, the urban natural space might merely require some cues of care, i.e., visible indications of human maintenance $[9,24,102,131-133]$. This is supported by our finding that the meadow scenario was positively evaluated by "city types" once it had an acceptance stripe (Table A4). Such acceptance stripes should be complemented by information boards that explain the ecological value of the management measures undertaken [75].

Our finding of a rejection of a lawn scenario by "country types" (Table A3) is not unusual. It corresponds to the finding that people tend to be more open towards conservation issues when they live more closely in contact with nature during their lifetime $[41,87,134,135]$. This is probably the case for the "country types" in our study.

\subsection{Commitment to Nature Conservation}

Participants who stated some form of commitment to nature conservation were, as expected, in favor of meadow scenarios, whereas they rejected lawn scenarios. In contrast, participants who were not involved in nature conservation preferred lawn scenarios and rejected meadow scenarios (Tables A3 and A4).

Participants who state some form of commitment to nature conservation probably have stronger ties to nature. Such closeness to nature can result, for example, from experiences of the natural world during childhood [22,136,137]. Several studies have confirmed that urban biodiversity is more appreciated by people who have a stronger connection to nature $[1,22,87,138]$.

Furthermore, the professional background of the participants of our questionnaire needs to be considered, since experts and laypeople evaluate the meanings and values of urban nature differently $[22,24,93,111,117,139,140]$. Fischer et al. [22] found that green experts appreciate plant species richness more than non-experts. Moreover, Hoyle et al. [24] showed that experts experience restorative relaxation to a lesser extent than non-professionals when in contact with nature. This needs to be taken into account by the planners of functional demand-orientated green space design.

\subsection{Non-Students}

In our study, non-students preferred meadow scenarios and rejected scenarios with lawns, unnatural green spaces, and acceptance stripes (Tables A1 and A2). According to BMU (Bundesministerium für Umwelt - the Federal Ministry for the Environment) [77], the use, meaning, and value of urban green spaces are generally linked to education, income, and social milieu.

Half of the non-students in our study were research associates; the other half were non-academic staff whose educational background was not noted. Referring to research associates, BMU [77] found that the willingness to contribute to biodiversity conservation was dependent on the degree of formal education. However, BMU [77] also determined that people with a medium level of education attached greater personal value to nature in the city than people with a high formal level of education. This possibly explains the found preference for urban nature by the non-academic staff in our survey (Tables A1 and A2).

Another explanation with respect to income was suggested by studies on environmental justice in cities (cf., [141]). Since low-income households are generally under-resourced in terms of green or even open spaces in their environment [23,77], urban green spaces are a crucial resource for these groups in terms of recreation and restorative effects [77]. Hence, the conservation of urban biodiversity plays an important role for the quality of life, in particular for marginalized individuals, and contributes to 
their social integration [77,142]. According to BMU [77], for people with a high household income, urban biodiversity has an important function in terms of the market value of land and buildings. Furthermore, neighborhoods in which a higher household income is the norm have a greater diversity of plants or total vegetation coverage, an aspect assigned to a 'luxury effect' [22,102,143-145].

Generally, well-situated milieus seem to show a stronger consciousness of nature than socially disadvantaged milieus [77].

The rejection of the unnatural green space by non-students in our study might be related to the effect of the seed mixture with especially bright flowers on the viewer. The suggestion has been made that planting experienced as strongly appealing may result in 'arousal', whereas 'deactivation' and eventually restorative relaxation might arise in response to a quieter planting style [24]. The highest aesthetic estimation of planting was found for colorful vegetation above a certain threshold of total flower coverage [24]. In comparison, a low aesthetic effect was experienced for vegetation with lower total flower coverage (2-9\%), although the greatest restorative relaxation effect was found for this scenario [24].

The comprehension of human preferences with respect to different landscape stimuli might resolve the sometimes contradictory evidence (e.g., $[146,147])$ with regard to the interrelation between aesthetic preference, restorative relaxation effect, and well-being [24]. Even though the aesthetic perception of the vegetation can have an influence on mood [24], restorative relaxation and well-being seem to depend more on factors such as demographic data including household income and employment [24]. These factors have been found to exert a substantial influence on mental distress and well-being $[24,148,149]$.

\subsection{Students}

Students preferred lawns and rejected meadow scenarios (Tables A1 and A2). This is in agreement with BMU [77]: for formally highly educated people, urban nature does not have such high personal meaning, and their access to nature in as many parts of the city as possible is mentioned less often as being important. However, a more differentiated assessment was obtained with regard to the separate faculties of the university (see below).

\subsection{Faculties}

We are not aware of any previous research that has considered the assignment of academic respondents to their different faculties. In the following, we compare the assessments of the students with regard to the various faculties to which they belong with the assessment of the "general" student category.

In our study, the assessment of the student members of the Medicine and Economic Sciences faculties did not differ from the "general" student category, since they preferred lawn scenarios and rejected a meadow scenario. The student members of the Humanities faculty showed only preferences for lawn scenarios and did not reject any of the presented scenarios (Table A3). In the Law faculty, even though the students preferred lawn scenarios, they also appreciated a scenario with a meadow. Students of the Theology faculty preferred either a lawn scenario or a meadow scenario (Tables A3 and A4). In the Social Sciences faculty, students preferred the unnatural green space scenario and rejected lawn scenarios (Tables A3 and A4). Previous studies have indicated that flowers can evoke strong positive emotions [24,150], and many studies have revealed a preference for colorful flowers in various landscape contexts (e.g., [30,79,85,87,97,151,152]). The appreciation of colorful flowers has also been associated with evolutionary theory $[24,85,152]$, since flowers indicate a rich environment $[24,85,94,133,152,153]$ and serve as cues of care, i.e., visible indicators that some form of human maintenance has been performed on these sites [24,94,133,153].

An opposing assessment as compared with the "general" student category was shown by the student members of the Natural Sciences faculty, who preferred a meadow scenario and rejected lawn scenarios (Tables A3 and A4). Similar to those active in nature conservation, this faculty might have 
a stronger connection to nature and/or the students might possess a different level of knowledge regarding care concepts for nature conservation compared with the other faculties.

4.6. Age

Although BMU [77] found that people under 30 years (18-29 years) showed a greater knowledge of biodiversity than older people, younger people attached greater value to urban nature than older ones only with respect to exercise and sports activities. Additionally, hay fever is more common in people under 40 years old in comparison with older generations [154]. These results are in agreement with those of our study, in which younger participants (0-20-year-olds and 20-40-year-olds) rejected meadow scenarios, with the youngest participants additionally preferring lawn scenarios.

As mentioned above, BMU [77] revealed that younger people attached a lower value to urban nature than older generations, especially those aged 50 and over. This study also found a strong preference for nature in the city among 50 - to 65 -year-olds. Our results agree with this, since the older participants (40-60-year-olds and $\geq 60$-year-olds) generally preferred meadow scenarios and rejected lawn scenarios, although one of these scenarios with an additional sculpture was appreciated by 40 - to 60-year-old people only.

\subsection{Family Status}

People with children preferred meadow scenarios and rejected lawn scenarios (Tables A1 and A2). This is in accordance with BMU [77], which showed that $>90 \%$ of the participants attached crucial significance to bringing nature closer to their children during their upbringing.

\subsection{Gender}

In our study, women rejected lawn scenarios. This agrees with the findings of BMU [77], which showed that women (in comparison to men) are often more sensitive to the plight of nature and strongly encourage principles of sustainability. Nevertheless, in our study, women had no preference for the various meadow scenarios, although BMU [77] found that nature in the city is more valuable for women than for men.

While, in our study, men indeed mostly preferred lawn scenarios (Table A1), they also preferred one scenario with a meadow (Table A2). In addition, they rejected both a meadow and a lawn scenario, demonstrating that demographic affiliation is not the only significant factor here. As perception is a combination of human factors and the physical characteristics of a scenario [79,111-113], the overall setting always has to be taken into account, i.e., the evaluation of a landscape is contextdependent $[9,22,91,98,133,155-157]$.

\subsection{Importance of the Overall Setting of the Urban Green Area}

Our study did not test any preferences for different periods of the year, since it only presented scenarios depicting the growing season.

With reference to the context of green spaces in front of buildings, the observed preference or rejection of green spaces in combination with a corresponding asphalt content is of interest for future research, especially in view of the partly opposing preferences shown by our demographic groups. The results might help to specify ways to employ a green space in front of a building (e.g., a lawn with a large forecourt). Our participants partly appreciated different forecourt sizes as a background scenario, e.g., a meadow with a large forecourt and a pathway. This shows that some scope exists to implement public green spaces with respect to the different demographic groups. A more differentiated evaluation of the demographic groups is thus needed. Of particular interest are the cases in which an existing preference for lawns could be changed in a way that resulted in an additional preference for a meadow (as shown by "city types", members of the Theology faculty, members of the Law faculty, and men). These cases indicate that the acceptability of nature in urban areas can be increased by modifying the respective environment. In the case of "city types", this can be achieved through an acceptance stripe. 
We found that the evaluation of a landscape is dependent on the context, since some background scenarios were rejected in one composition but preferred in another. For example, the positive way in which the 40- to 60-year-old cohort regarded the lawn scenario in combination with a sculpture (Table A1) shows that a compromise can be achieved in terms of the shared use of open public green spaces by different social groups. If a lawn is desired by most of the population at a particular location for a particular purpose (e.g., barbecue, sports activities, relaxation), the employment of a sculpture might provide an additional positive aspect for a green space type that would otherwise be rejected. Daniels et al. [8] pointed out that no structural element is significant or insignificant by itself, but that each element needs to be considered from a specific aspect, i.e., ecological, (micro)climatic, or social. The specific design and the characteristics (artificial/natural) of the respective structural element must however be taken into account $[1,8,139,158,159]$. For instance, an artificial element might have a high social value but, at the same time, be of low ecological importance [8]. This supports the need for the multidimensional assessment $[8,160]$ of the various aspects (ecological, microclimatic, social) provided by a structural element [8].

For urban green area planning, the multifunctionality of the whole site must be considered [8,41,160-163] with regard to ecological, climatic, and social aspects [8,163]. The purpose (e.g., recreation, socializing) for which the green place is to be used must be differentiated [8]. Accordingly, all the green spaces of a city should be evaluated regarding their intended use by its citizens. This implies heterogeneous measures that consider biodiversity in addition to ecosystem services $[90,164,165]$, while also providing a usable green space usable for the urban population $[7,9,22,126,166,167]$. For instance, a natural meadow would not remain a frequently visited sunbathing area in a park, whereas a lawn would fulfill this function much better [8].

Furthermore, the perspective from which a site is viewed also seems to be important. Studies that are based on the evaluation of images taken from diverse angles, distances, and viewing perspectives have indicated that these overall setting factors affect the overall results of landscape assessment $[1,75,90,168-170]$. However, the ways in which observations from different perspectives influence the perception of an individual location remain unclear [90]. Software such as the "Virtual Garden Planner" suggested by Shwartz et al. [138] offer possibilities for the detailed designing of relevant scenarios [8].

The strategy of zoning suggested by Borgström et al. [171] prioritizes the implementation of different objectives at different sites [8]. This approach can help to establish meadows in areas where no lawns or intensively managed green spaces are necessary for the population. In addition, unused spaces (bare or mown), such as courtyards, peripheral areas, flat roofs, tramways, transmission line rights-of-way, and even vertical structures (e.g., walls), can be designed in a more biodiversity-friendly fashion $[3,23,90]$. Other measures can enhance biodiversity, for instance, the use of seeds from a regional gene pool $[90,172]$. Moreover, a consensus regarding the amount of structures (with ecological and climatic qualities) and structural elements should occur during urban planning in order to increase urban green space sustainability [8].

In agreement with Daniels et al. [8], we suggest a hybrid concept for the design of urban green spaces that applies the above-mentioned multidimensional assessment and zoning approaches. This concept requires communication with citizens so that both a demand-orientated green space can be offered (i.e., appropriate weighting of the various aspects (ecological, climatic, social) [8]) and an increase in biodiversity can be implemented at the same time. Ecologically valuable environments will only receive more support and thus become more sustainable if they elicit both joy and acceptance in the urban population $[46,79,173]$.

\section{Conclusions}

Our survey has revealed that for "city types", a preference for natural meadows in a medium sized city such as Tübingen (southwest Germany) can be achieved through an acceptance stripe, i.e., mowed stripes only at the margins around an actual natural green space. Since urban areas contain 
more than half of the global human population $[41,174,175]$, and since these numbers are strongly increasing [176], this is an important issue and a promising starting point for improving biodiversity in cities. Such acceptance stripes should be complemented by information boards that explain the ecological value of the management measures undertaken. A strategy of zoning that takes into account different objectives at different sites would foster more biodiversity in areas that are not heavily utilized in the form of lawns. This requires good communication of the biodiversity measures to the citizens, with special reference to the intended extensification of urban green space. Whereas 40 - to 60 -year-olds consistently rejected intensely maintained lawns in the present study, their perception was positive if the lawn occurred in combination with a sculpture. This example shows that compromises for various usage requirements are attainable. In general, such compromise solutions can be achieved by the multidimensional assessment of urban green space, together with the consideration of various criteria (ecological, microclimatic, and social). This requires an ongoing evaluation of all management concepts (e.g., acceptance stripes) and structural elements that are planned during urban green maintenance. The importance of involving a social perspective in the form of citizen participation has been pointed out (e.g., $[8,78,87,139,177-182])$, because people will not protect and sustain landscapes that they do not value and enjoy $[91,173]$. Therefore, urban green spaces should ideally be designed in close cooperation with the relevant citizens $[8,183,184]$. In principle, each space must be evaluated for its advantages within the framework of the residents' needs [9]. After all, the positive perception of the population is ultimately the decisive factor.

Further research is needed with respect to landscape preference and its different aspects for different social groups. This knowledge must then be used to develop communication strategies that explain to the general public the ecological value of extensification measures that are required in order to implement nature conservation in the city.

Author Contributions: M.Z. and P.A.U. conceived and designed the experiments; M.Z. performed the experiments and analyzed the data together with O.B.; M.Z., P.A.U., and O.B. contributed ideas and wrote the paper. All authors have read and agreed to the published version of the manuscript.

Funding: This research was funded by Open Access Publishing Fund of University of Tübingen.

Acknowledgments: Theresa Jones corrected the English. We thank the anonymous participants of our questionnaire for their time and their useful suggestions and comments. We also thank the anonymous reviewers for their thorough correction and helpful suggestions.

Conflicts of Interest: The authors declare no conflict of interest. 


\section{Appendix A}

Table A1. Table of all the presented lawn areas that were significant with respect to age, gender, people with children, students, and non-students. The table presents the number of choices for a certain green space by the respective sociodemographic group (standardized residuals in brackets). Whereas a positive residual indicates that the scenario was appreciated by the relevant demographic group (bold type), a negative residual indicates that the scenario was disliked (normal typeface). Question 3 was divided into four sub-questions; each picture was presented twice as two separate questions: the results of (i) the first sub-question are shown in the upper line; results of (ii) the second sub-question in the lower line.

\begin{tabular}{|c|c|c|c|c|c|c|c|c|}
\hline & \multicolumn{3}{|c|}{ Age } & \multicolumn{2}{|c|}{ Gender } & \multirow{2}{*}{$\begin{array}{c}\begin{array}{c}\text { Has } \\
\text { Children }\end{array} \\
\text { Yes } \\
\end{array}$} & \multicolumn{2}{|c|}{ Student } \\
\hline & I. & III. & IV. & Male & Female & & Yes & No \\
\hline Lawn (1H) & & & & $29(3.0)$ & & & & \\
\hline $\begin{array}{c}\text { Lawn, } \\
\text { Large Forecourt (2.1G) }\end{array}$ & & $10(-2.9)$ & & $71(3.6)$ & $77(-2.4)$ & $13(-2.3)$ & $123(2.4)$ & $25(-3.4)$ \\
\hline $\begin{array}{l}\text { Lawn, } \\
\text { Small Forecourt }(2.1 \mathrm{H})\end{array}$ & $30(4.0)$ & $14(-2.9)$ & & $82(3.3)$ & $98(-2.2)$ & & & $38(-2.8)$ \\
\hline $\begin{array}{c}\text { Lawn, } \\
\text { Pathway (2.1I) }\end{array}$ & & $11(-2.3)$ & & & & & & \\
\hline $\begin{array}{c}\text { Lawn, } \\
\text { Pathway (2.2I) }\end{array}$ & & $72(-3.1)$ & & & & & & $165(-2.8)$ \\
\hline $\begin{array}{c}\text { Lawn, } \\
\text { Large Forecourt (2.3G) }\end{array}$ & & $46(-2.1)$ & & $156(3.4)$ & $218(-2.4)$ & $45(-2.1)$ & $290(2.4)$ & $86(-3.4)$ \\
\hline $\begin{array}{l}\text { Lawn, } \\
\text { Small Forecourt }(2.3 \mathrm{H})\end{array}$ & & & $6(-3.1)$ & $171(-2.3)$ & & & & \\
\hline $\begin{array}{c}\text { Lawn, } \\
\text { Pathway (2.3I) }\end{array}$ & & $40(-4.8)$ & & & & & & \\
\hline $\begin{array}{c}\text { Lawn without Trees } \\
\text { Bench (3A) }\end{array}$ & ii: 10 (3.4) & & & & & & & \\
\hline $\begin{array}{l}\text { Lawn without Trees } \\
\text { Bench, Lanterns (3B) }\end{array}$ & & $\begin{array}{l}\text { i: } 1(-2.4) \\
\text { ii: } 1(-2.1)\end{array}$ & & & & & & i: $5(-2.5)$ \\
\hline Lawn without Trees & & & & i: $21(3.0)$ & & & & \\
\hline Bench, Lanterns, Sculpture (3C) & & & & ii: $9(2.2)$ & & & & \\
\hline $\begin{array}{c}\text { Lawn with Trees } \\
\text { Bench, Lanterns (3E) }\end{array}$ & & i: $21(-2.5)$ & & ii: $86(-2.3)$ & & i: $23(-2.1)$ & & \\
\hline $\begin{array}{l}\text { Lawn with Trees } \\
\text { Bench, Lanterns, Sculpture (3F) }\end{array}$ & & ii: 35 (3.0) & & & & & & \\
\hline
\end{tabular}


Table A2. Table of all the presented meadow areas that were significant with respect to age, gender, people with children, students, and non-students. The table presents the number of choices for a certain green space by the respective sociodemographic group (standardized residuals in brackets). Whereas a positive residual indicates that the scenario was appreciated by the relevant demographic group (bold type), a negative residual indicates that the scenario was disliked (normal typeface). Question 3 was divided into four sub-questions; each picture was presented twice as two separate questions: the results of (i) the first sub-question are shown in the upper line; results of (ii) the second sub-question in the lower line.

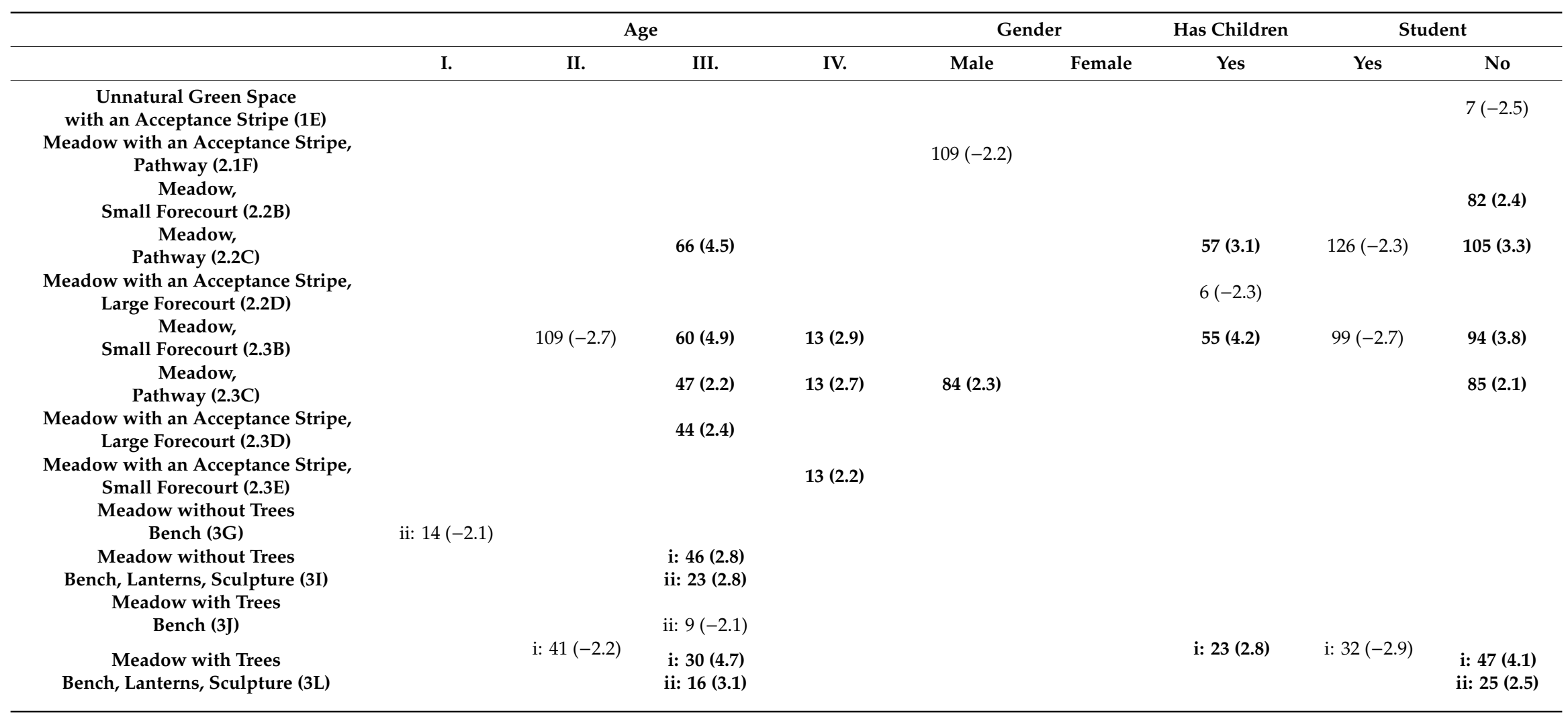


Table A3. Table of the all presented lawn areas that were significant with respect to faculties, commitment to nature conservation, and peoples' self-perception. The table presents the number of choices for a certain green space by the respective sociodemographic group (standardized residuals in brackets). Whereas a positive residual indicates that the scenario was appreciated by the relevant demographic group (bold type), a negative residual indicates that the scenario was disliked (normal typeface). Question 3 was divided into four sub-questions; each picture was presented twice as two separate questions: the results of (i) the first sub-question are shown in the upper line; results of (ii) the second sub-question in the lower line.

\begin{tabular}{|c|c|c|c|c|c|c|c|c|c|c|c|}
\hline & & & & Faculty & & & & Commitmer & onservation & Self-Perc & ption \\
\hline & I. & II. & III. & IV. & V. & VI. & VII. & Yes & No & Country Type & City Type \\
\hline Lawn (1G) & & & $10(2.4)$ & & & & $10(-2.1)$ & & & & \\
\hline Lawn $(1 \mathrm{H})$ & & $4(2.2)$ & & & & & & $15(-2.5)$ & $37(2.7)$ & & \\
\hline $\begin{array}{l}\text { Lawn, } \\
\text { Large Forecourt (2.1G) }\end{array}$ & & $14(5.0)$ & & & & & $33(-2.5)$ & & & & $73(2.7)$ \\
\hline $\begin{array}{c}\text { Lawn, } \\
\text { Small Forecourt (2.1H) }\end{array}$ & & & & & $15(3.5)$ & & & $72(-2.5)$ & $108(2.8)$ & & \\
\hline $\begin{array}{c}\text { Lawn, } \\
\text { Pathway (2.1I) }\end{array}$ & & & & $38(2.1)$ & & & & $47(-2.7)$ & $82(3.0)$ & & \\
\hline $\begin{array}{c}\text { Lawn, } \\
\text { Large Forecourt (2.2G) }\end{array}$ & & $8(2.8)$ & & & & & & $56(-2.4)$ & $86(2.5)$ & $68(-2.2)$ & $68(2.3)$ \\
\hline $\begin{array}{l}\text { Lawn, } \\
\text { Small Forecourt }(2.2 \mathrm{H})\end{array}$ & & & $49(2.7)$ & & & $19(-2.1)$ & & $219(-2.5)$ & $260(2.7)$ & & \\
\hline $\begin{array}{c}\text { Lawn, } \\
\text { Pathway (2.2I) }\end{array}$ & & & & & & & & $294(-2.2)$ & 324 (2.4) & & \\
\hline $\begin{array}{l}\text { Lawn, } \\
\text { Large Forecourt (2.3G) }\end{array}$ & & $16(2.3)$ & & & & $15(-2.4)$ & & $156(-3.1)$ & $214(3.4)$ & & \\
\hline $\begin{array}{c}\text { Lawn, } \\
\text { Small Forecourt (2.3H) }\end{array}$ & & & & & & & & $302(-2.4)$ & $338(2.5)$ & & \\
\hline $\begin{array}{c}\text { Lawn, } \\
\text { Pathway (2.3I) }\end{array}$ & & & & & & & $122(-2.2)$ & $231(-2.4)$ & $269(2.5)$ & & \\
\hline $\begin{array}{l}\text { Lawn without Trees } \\
\text { Bench (3A) }\end{array}$ & & & & & i: $5(2.7)$ & & & & & & \\
\hline $\begin{array}{l}\text { Lawn without Trees } \\
\text { Bench, Lanterns (3B) }\end{array}$ & ii: 5 (3.8) & i: 4 (2.5) & & & & & & & & & \\
\hline $\begin{array}{l}\text { Lawn without Trees } \\
\text { Bench, Lanterns, Sculpture (3C) }\end{array}$ & & ii: 2 (3.5) & & i: $15(3.0)$ & & & & & & & \\
\hline
\end{tabular}


Table A4. Table of all the presented meadow areas that were significant with respect to faculties, commitment to nature conservation, and peoples' self-perception. The table presents the number of choices for a certain green space by the respective sociodemographic group (standardized residuals in brackets). Whereas a positive residual indicates that the scenario was appreciated by the relevant demographic group (bold type), a negative residual indicates that the scenario was disliked (normal typeface).

\begin{tabular}{|c|c|c|c|c|c|c|c|c|c|}
\hline & \multicolumn{6}{|c|}{ Faculty } & \multicolumn{2}{|c|}{ Commitment to Conservation } & \multirow{2}{*}{$\begin{array}{c}\text { Self-Perceptior } \\
\text { City Type }\end{array}$} \\
\hline & I. & II. & III. & V. & VI. & VII. & Yes & No & \\
\hline Unnatural Green Space (1F) & & & & & $30(2.1)$ & & & & \\
\hline $\begin{array}{c}\text { Meadow, } \\
\text { Small Forecourt (2.1B) }\end{array}$ & & & & & & & & $198(-2.1)$ & \\
\hline $\begin{array}{c}\text { Meadow, } \\
\text { Large Forecourt (2.2A) }\end{array}$ & & $4(3.1)$ & & & & & & & \\
\hline $\begin{array}{c}\text { Meadow, } \\
\text { Small Forecourt (2.2B) }\end{array}$ & & & & & & & $127(2.4)$ & $63(-2.6)$ & \\
\hline $\begin{array}{c}\text { Meadow, } \\
\text { Pathway 2.2C) }\end{array}$ & & & & & & & $160(3.2)$ & $71(-3.4)$ & \\
\hline $\begin{array}{c}\text { Meadow with an Acceptance Stripe, } \\
\text { Small Forecourt (2.2E) }\end{array}$ & $17(2.3)$ & & & & & & & & \\
\hline $\begin{array}{c}\text { Meadow with an Acceptance Stripe, } \\
\text { Pathway (2.2F) }\end{array}$ & & & & & & & $336(3.1)$ & $189(-3.3)$ & \\
\hline $\begin{array}{c}\text { Meadow, } \\
\text { Large Forecourt (2.3A) }\end{array}$ & & & & & & & $100(2.2)$ & $49(-2.3)$ & \\
\hline $\begin{array}{l}\text { Meadow, } \\
\text { Small Forecourt (2.3B) }\end{array}$ & & & & & & & & & $49(-2.5)$ \\
\hline $\begin{array}{c}\text { Meadow, } \\
\text { Pathway (2.3C) }\end{array}$ & & & $5(-2.2)$ & & & $67(2.3)$ & $141(2.8)$ & $66(-3.0)$ & \\
\hline $\begin{array}{l}\text { Meadow with an Acceptance Stripe, } \\
\text { Small Forecourt (2.3E) }\end{array}$ & & & & $1(-2.1)$ & & $74(2.1)$ & $148(2.1)$ & $84(-2.2)$ & $103(2.1)$ \\
\hline $\begin{array}{c}\text { Meadow with an Acceptance Stripe, } \\
\text { Pathway (2.3F) }\end{array}$ & & & & & & & & $96(-2.1)$ & \\
\hline
\end{tabular}




\section{Appendix B}

Table A5. Photo usage and details of Question 1.

\begin{tabular}{|c|c|c|c|c|c|}
\hline & Natural Meadow (A and B) & Natural Meadow (C and D) & Unnatural Meadow (E and F) & Lawn (G) & Lawn $(\mathrm{H})$ \\
\hline & Shooting date: & Shooting date: & Shooting date: & Shooting date: & Shooting date: \\
\hline Scenario & 1 June 2015 & 7 June 2012 & 20 July 2015 & 7 June 2012 & 20 July 2015 \\
\hline & Camera: & Camera: & Camera: & Camera: & Camera: \\
\hline & Canon Power Shot A2200 & FUJIFILM FinePix Z33WP & Nikon D5100 & FUJIFILM FinePix Z33WP & Nikon D5100 \\
\hline & Focal length: & Focal length: & Focal length: & Focal length: & Focal length: \\
\hline & $5 \mathrm{~mm}$ & $6 \mathrm{~mm}$ & $18 \mathrm{~mm}$ & $6 \mathrm{~mm}$ & $18 \mathrm{~mm}$ \\
\hline \multirow{6}{*}{ Image of Green Space } & Shooting date: & Shooting date: & Shooting date: & Shooting date: & Shooting date: \\
\hline & 1 June 2015 & 7 June 2012 & 20 July 2015 & 19 October 2015 & 19 October 2015 \\
\hline & Camera: & Camera: & Camera: & Camera: & Camera: \\
\hline & Canon Power Shot A2200 & FUJIFILM FinePix Z33WP & Nikon D5100 & Nikon D5100 & Nikon D5100 \\
\hline & Focal length: & Focal length: & Focal length: & Focal length: & Focal length: \\
\hline & $5 \mathrm{~mm}$ & $6 \mathrm{~mm}$ & $18 \mathrm{~mm}$ & $32 \mathrm{~mm}$ & $18 \mathrm{~mm}$ \\
\hline \multirow{5}{*}{$\begin{array}{l}\text { Additionally Used } \\
\text { Image of Green Space }\end{array}$} & & & Shooting date: & & \\
\hline & & & 7-June-2014 & & \\
\hline & & & Camera: & & \\
\hline & & & Leica V-LUX1 & & \\
\hline & & & $\begin{array}{l}\text { Focal length: } \\
7 \mathrm{~mm}\end{array}$ & & \\
\hline \multirow{5}{*}{ Acceptance Stripe } & & Shooting date: & Shooting date: & & \\
\hline & & 19-October-2015 & 19-October-2015 & & \\
\hline & & Camera: & Camera: & & \\
\hline & & Nikon D5100 & Nikon D5100 & & \\
\hline & & $\begin{array}{l}\text { Focal length: } \\
32 \mathrm{~mm}\end{array}$ & $\begin{array}{l}\text { Focal length: } \\
18 \mathrm{~mm}\end{array}$ & & \\
\hline \multirow{2}{*}{ Pathway } & Shooting date: & $\begin{array}{l}32 \mathrm{~mm} \\
\text { Shooting date: }\end{array}$ & $\begin{array}{l}18 \mathrm{~mm} \\
\text { Shooting date: }\end{array}$ & Shooting date: & Shooting date: \\
\hline & 8 July 2015 & 8 July 2015 & 13 January 2013 & 8 July 2015 & 13 January 2013 \\
\hline \multirow{10}{*}{ Background Merging } & Camera: & Camera: & Camera: & Camera: & Camera: \\
\hline & Nikon D5100 & Nikon D5100 & FUJIFILM FinePix JX350 & Nikon D5100 & FUJIFILM FinePix JX350 \\
\hline & Focal length: & Focal length: & Focal length: & Focal length: & Focal length: \\
\hline & $35 \mathrm{~mm}$ & $35 \mathrm{~mm}$ & $5 \mathrm{~mm}$ & $35 \mathrm{~mm}$ & $5 \mathrm{~mm}$ \\
\hline & & & Shooting date: & & Shooting date: \\
\hline & & & 18 October 2015 & & 18 October 2015 \\
\hline & & & Camera: & & Camera: \\
\hline & & & Nikon D5100 & & Nikon D5100 \\
\hline & & & Focal length: & & Focal length: \\
\hline & & & $18 \mathrm{~mm}$ & & $18 \mathrm{~mm}$ \\
\hline
\end{tabular}


Table A6. Photo usage and details of Question 2.1.

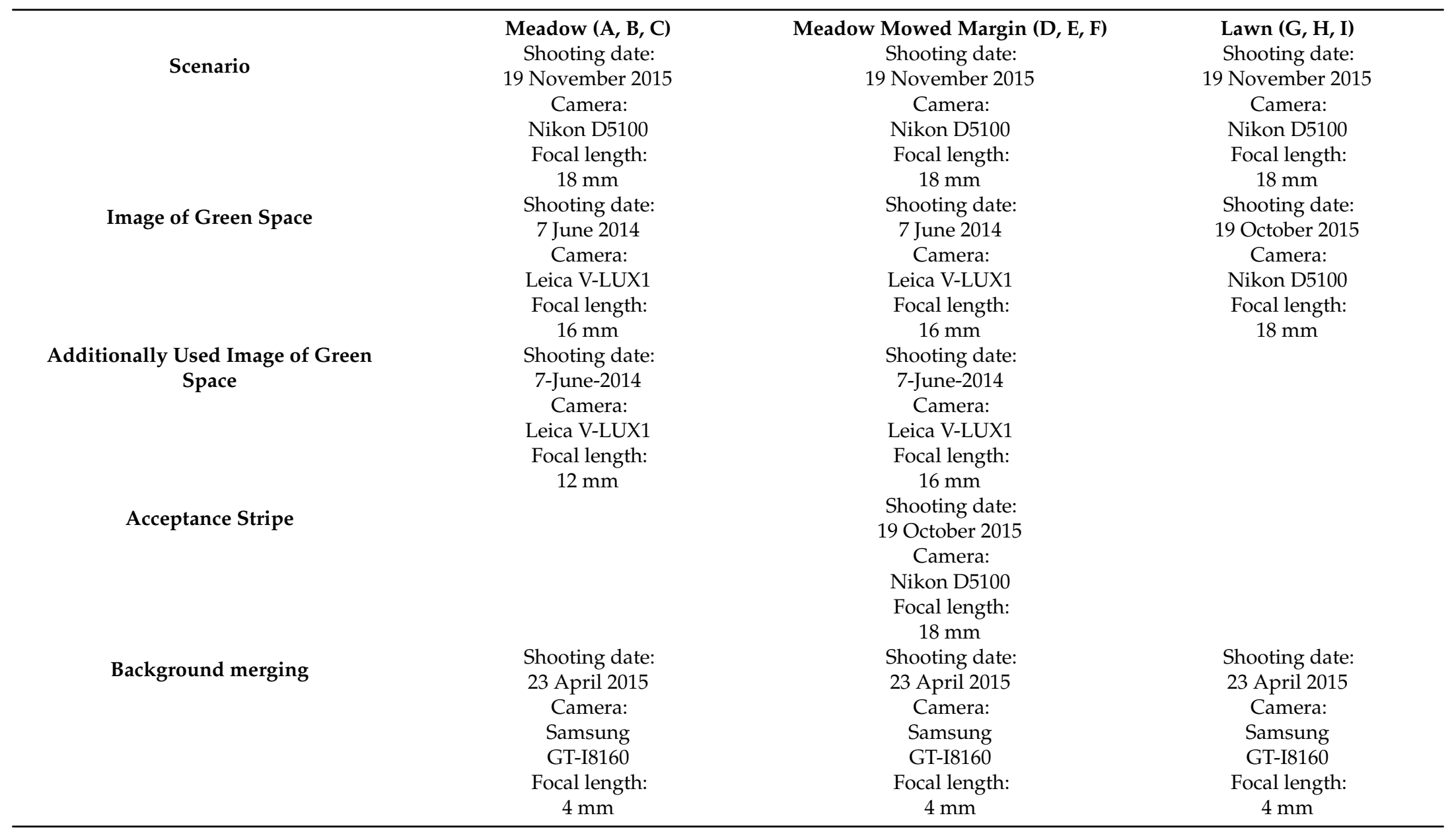


Table A7. Photo usage and details of Question 2.2.

\begin{tabular}{|c|c|c|c|c|c|c|}
\hline \multirow{7}{*}{ Scenario } & Meadow (A) & Meadow(B and C) & Meadow Mowed Margin (D and E) & Meadow Mowed Margin (F) & Lawn (G) & Lawn (H and I) \\
\hline & Shooting date: & Shooting date: & Shooting date: & Shooting date: & Shooting date: & Shooting date: \\
\hline & 17 October 2015 & 17 October 2015 & 17 October 2015 & 17 October 2015 & 17 October 2015 & 17 October 2015 \\
\hline & Camera: & Camera: & Camera: & Camera: & Camera: & Camera: \\
\hline & Nikon D5100 & Nikon D5100 & Nikon D5100 & Nikon D5100 & Nikon D5100 & Nikon D5100 \\
\hline & Focal length: & Focal length: & Focal length: & Focal length: & Focal length: & Focal length: \\
\hline & $18 \mathrm{~mm}$ & $18 \mathrm{~mm}$ & $18 \mathrm{~mm}$ & $18 \mathrm{~mm}$ & $18 \mathrm{~mm}$ & $18 \mathrm{~mm}$ \\
\hline \multirow{6}{*}{$\begin{array}{l}\text { Image of Green } \\
\text { Space }\end{array}$} & Shooting date: & Shooting date: & Shooting date: & Shooting date: & Shooting date: & Shooting date: \\
\hline & 1 August 2012 & 1 August 2012 & 1 August 2012 & 1 August 2012 & 19 October 2015 & 19 October 2015 \\
\hline & Camera: & Camera: & Camera: & Camera: & Camera: & $\begin{array}{l}\text { Camera: } \\
\text { Cam }\end{array}$ \\
\hline & FUJIFILM FinePix JX350 & FUJIFILM FinePix JX350 & FUJIFILM FinePix JX350 & FUJIFILM FinePix JX350 & Nikon D5100 & Nikon D5100 \\
\hline & Focal length: & Focal length: & Focal length: & Focal length: & Focal length: & Focal length: \\
\hline & $5 \mathrm{~mm}$ & $5 \mathrm{~mm}$ & $5 \mathrm{~mm}$ & $5 \mathrm{~mm}$ & $18 \mathrm{~mm}$ & $18 \mathrm{~mm}$ \\
\hline \multirow{5}{*}{$\begin{array}{l}\text { Additionally Used } \\
\text { Image of Green } \\
\text { Space }\end{array}$} & & $\begin{array}{l}\text { Shooting date: } \\
1 \text { August } 2012\end{array}$ & $\begin{array}{l}\text { Shooting date: } \\
1 \text { August } 2012\end{array}$ & $\begin{array}{l}\text { Shooting date: } \\
1 \text { August } 2012\end{array}$ & & \\
\hline & & Camera: & Camera: & Camera: & & \\
\hline & & FUJIFILM FinePix JX350 & FUJIFILM FinePix JX350 & FUJIFILM FinePix JX350 & & \\
\hline & & Focal length: & Focal length: & Focal length: & & \\
\hline & & $5 \mathrm{~mm}$ & $5 \mathrm{~mm}$ & $5 \mathrm{~mm}$ & & \\
\hline \multirow{5}{*}{$\begin{array}{l}\text { Acceptance } \\
\text { Stripe }\end{array}$} & & & Shooting date: & Shooting date: & & \\
\hline & & & 19 October 2015 & 19 October 2015 & & \\
\hline & & & Camera: & Camera: & & \\
\hline & & & Nikon D5100 & Nikon D5100 & & \\
\hline & & & $\begin{array}{l}\text { Focal length: } \\
18 \mathrm{~mm}\end{array}$ & $\begin{array}{l}\text { Focal length: } \\
18 \mathrm{~mm}\end{array}$ & & \\
\hline & Shooting date: & & Shooting date: & & Shooting date: & \\
\hline \multirow{5}{*}{ Merging } & 30 January 2016 & & 30 January 2016 & & 30 January 2016 & \\
\hline & Camera: & & $\begin{array}{l}\text { Camera: } \\
\text { S }\end{array}$ & & Camera: & \\
\hline & Nikon D5100 & & Nikon D5100 & & Nikon D5100 & \\
\hline & Focal length: & & Focal length: & & Focal length: & \\
\hline & $18 \mathrm{~mm}$ & & $18 \mathrm{~mm}$ & & $18 \mathrm{~mm}$ & \\
\hline
\end{tabular}


Table A8. Photo usage and details of Question 2.3.

\begin{tabular}{|c|c|c|c|}
\hline \multirow{7}{*}{ Scenario } & Meadow $(A, B, C)$ & Meadow Mowed Margin (D, E, F) & Lawn $(G, H, I)$ \\
\hline & Shooting date: & Shooting date: & Shooting date: \\
\hline & 17 October 2015 & 17 October 2015 & 17 October 2015 \\
\hline & Camera: & Camera: & Camera: \\
\hline & Nikon D5100 & Nikon D5100 & Nikon D5100 \\
\hline & Focal length: & Focal length: & Focal length: \\
\hline & $18 \mathrm{~mm}$ & $18 \mathrm{~mm}$ & $18 \mathrm{~mm}$ \\
\hline \multirow{6}{*}{ Image of Green Space } & Shooting date: & Shooting date: & Shooting date: \\
\hline & 1 August 2012 & 1 August 2012 & 19 October 2015 \\
\hline & Camera: & Camera: & Camera: \\
\hline & FUJIFILM FinePix JX350 & FUJIFILM FinePix JX350 & Nikon D5100 \\
\hline & Focal length: & Focal length: & Focal length: \\
\hline & $14 \mathrm{~mm}$ & $14 \mathrm{~mm}$ & $18 \mathrm{~mm}$ \\
\hline \multirow{6}{*}{ Acceptance Stripe } & & Shooting date: & \\
\hline & & 19 October 2015 & \\
\hline & & Camera: & \\
\hline & & Nikon D5100 & \\
\hline & & Focal length: & \\
\hline & & $18 \mathrm{~mm}$ & \\
\hline
\end{tabular}


Table A9. Photo usage and details of Question 3.

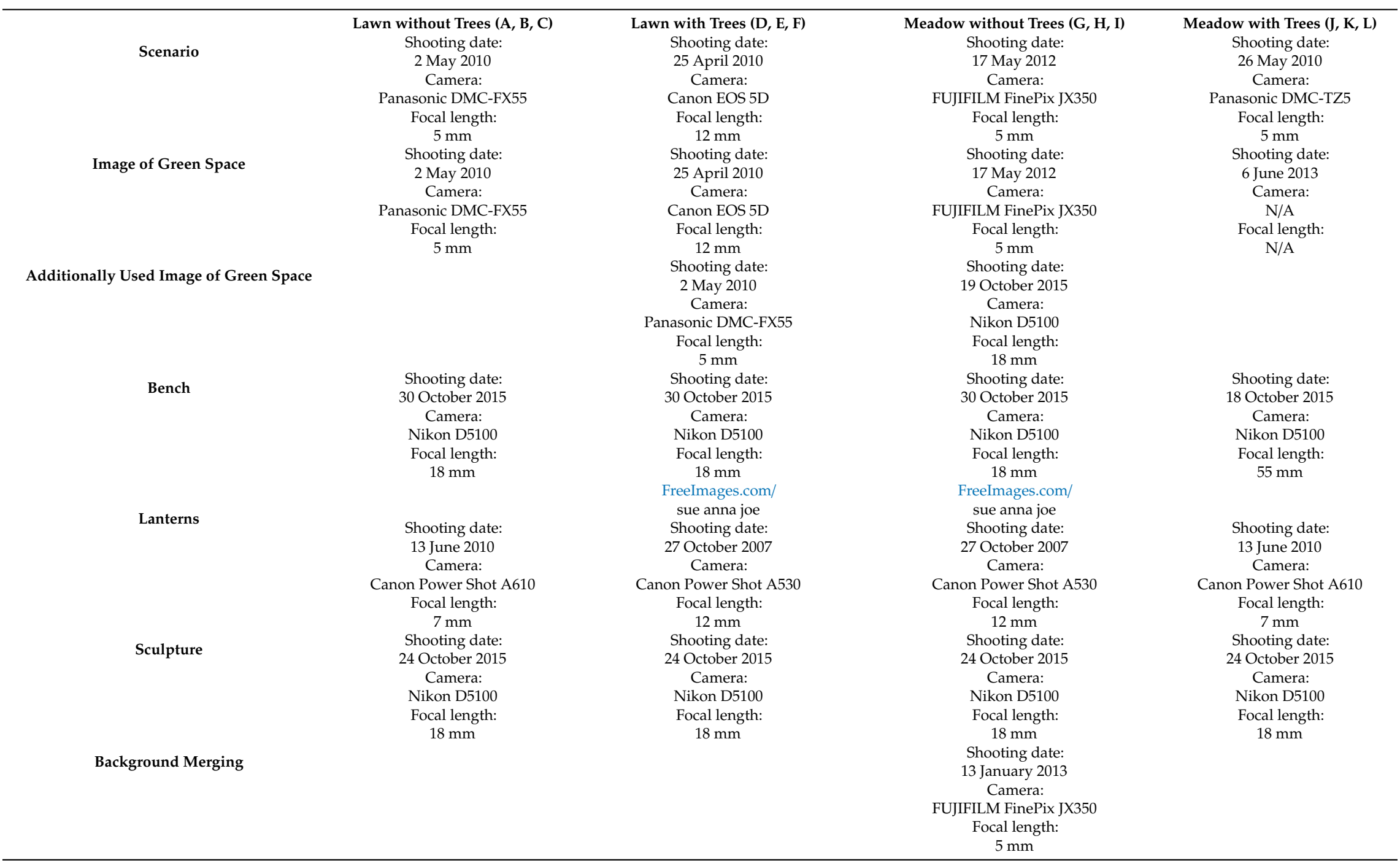




\section{References}

1. Southon, G.E.; Jorgensen, A.; Dunnett, N.; Hoyle, H.; Evans, K.L. Biodiverse perennial meadows have aesthetic value and increase residents' perceptions of site quality in urban green-space. Landsc. Urban Plan. 2017, 158, 105-118. [CrossRef]

2. Ineichen, S.; Klausnitzer, B.; Ruckstuhl, M. Stadtfauna; Haupt Verlag: Berne, Switzerland, 2012. (In German)

3. Obrist, M.K.; Sattler, T.; Home, R.; Gloor, S.; Bontadina, F.; Nobis, M.; Braaker, S.; Duelli, P.; Bauer, N.; Della Bruna, P. Biodiversität in der Stadt_F Für Mensch und Natur; Eidg. Forschungsanstalt für Wald, Schnee und Landschaft: Birmensdorf, Switzerland, 2012. (In German)

4. Goddard, M.A.; Dougill, A.J.; Benton, T.G. Scaling up from gardens: Biodiversity conservation in urban environments. Trends Ecol. Evol. 2010, 25, 90-98. [CrossRef] [PubMed]

5. Kong, F.; Yin, H.; Nakagoshi, N.; Zong, Y. Urban green space network development for biodiversity conservation: Identification based on graph theory and gravity modeling. Landsc. Urban Plan. 2010, 95, 16-27. [CrossRef]

6. Lindemann-Matthies, P.; Junge, X.; Matthies, D. The influence of plant diversity on people's perception and aesthetic appreciation of grassland vegetation. Biol. Conserv. 2010, 143, 195-202. [CrossRef]

7. Fuller, R.A.; Irvine, K.N.; Devine-Wright, P.; Warren, P.H.; Gaston, K.J. Psychological benefits of greenspace increase with biodiversity. Biol. Lett. 2007, 3, 390-394. [CrossRef]

8. Daniels, B.; Zaunbrecher, B.S.; Paas, B.; Ottermanns, R.; Ziefle, M.; Roß-Nickoll, M. Assessment of urban green space structures and their quality from a multidimensional perspective. Sci. Total Environ. 2018, 615, 1364-1378. [CrossRef]

9. Rega-Brodsky, C.C.; Nilon, C.H.; Warren, P.S. Balancing urban biodiversity needs and resident preferences for vacant lot management. Sustainability 2018, 10, 1679. [CrossRef]

10. Nielsen, A.B.; van den Bosch, M.; Maruthaveeran, S.; Konijnendijk van den Bosch, C.C. Species richness in urban parks and its drivers: A review of empirical evidence. Urban Ecosyst. 2014, 17, 305-327. [CrossRef]

11. Geslin, B.; Gauzens, B.; Thebault, E.; Dajoz, I. Plant pollinator networks along a gradient of urbanisation. PLoS ONE 2013, 8, e63421. [CrossRef] [PubMed]

12. Mace, G.M.; Norris, K.; Fitter, A.H. Biodiversity and ecosystem services: A multilayered relationship. Trends Ecol. Evol. 2012, 27, 19-26. [CrossRef]

13. Farinha-Marques, P.; Lameiras, J.M.; Fernandes, C.; Silva, S.; Guilherme, F. Urban biodiversity: A review of current concepts and contributions to multidisciplinary approaches. Innovation (Abingdon) 2011, 24, 247-271. [CrossRef]

14. Claßen, T. Empirische Befunde zum Zusammenhang von Landschaft und physischer Gesundheit. In Landschaft, Identität und Gesundheit; Gebhard, U., Kistemann, T., Eds.; Springer VS: Wiesbaden, Germany, 2016; pp. 71-91. (In German)

15. Janhäll, S. Review on urban vegetation and particle air pollution-Deposition and dispersion. Atmos. Environ. 2015, 105, 130-137. [CrossRef]

16. Calfapietra, C.; Fares, S.; Manes, F.; Morani, A.; Sgrigna, G.; Loreto, F. Role of Biogenic Volatile Organic Compounds (BVOC) emitted by urban trees on ozone concentration in cities: A review. Environ. Pollut. 2013, 183, 71-80. [CrossRef] [PubMed]

17. Henninger, S. Notwendiger Wandel im Umgang mit innerstädtischen Grünflächen. In Räume im Wandel; Junkernheinrich, M., Ziegler, K., Eds.; Springer VS: Wiesbaden, Germany, 2013; pp. 73-92. (In German)

18. Bowler, D.E.; Buyung-Ali, L.; Knight, T.M.; Pullin, A.S. Urban greening to cool towns and cities: A systematic review of the empirical evidence. Landsc. Urban Plan. 2010, 97, 147-155. [CrossRef]

19. Gebhard, U. Wie Wirken Natur und Landschaft auf Gesundheit, Wohlbefinden und Lebensqualität? Bundesamt für Naturschutz: Bonn, Germany, 2010. (In German)

20. Cervinka, R. Natur und Naturnahe Artefakte. Gesundheit, Wohlbefinden und Nachhaltige Entwicklung; Forum Österreichischer Wissenschaftler für Umweltschutz: Vienna, Austria, 2005. (In German)

21. Peters, K.B.M.; Elands, B.H.M.; Buijs, A.E. Social interactions in urban parks: Stimulating social cohesion? Urban For. Urban Green. 2010, 9, 93-100. [CrossRef]

22. Fischer, L.K.; Honold, J.; Cvejić, R.; Delshammar, T.; Hilbert, S.; Lafortezza, R.; Nastran, M.; Nielsen, A.B.; Pintar, M.; van der Jagt, A.P. Beyond green: Broad support for biodiversity in multicultural European cities. Glob. Environ. Chang. 2018, 49, 35-45. [CrossRef] 
23. Kim, M.; Rupprecht, C.; Furuya, K. Residents' perception of informal green space-A case study of Ichikawa City, Japan. Land 2018, 7, 102. [CrossRef]

24. Hoyle, H.; Hitchmough, J.; Jorgensen, A. All about the 'wow factor'? The relationships between aesthetics, restorative effect and perceived biodiversity in designed urban planting. Landsc. Urban Plan. 2017, 164, 109-123. [CrossRef]

25. Hartig, T.; Kahn, P.H. Living in cities, naturally. Science 2016, 352, 938-940. [CrossRef]

26. Carrus, G.; Scopelliti, M.; Lafortezza, R.; Colangelo, G.; Ferrini, F.; Salbitano, F.; Agrimi, M.; Portoghesi, L.; Semenzato, P.; Sanesi, G. Go greener, feel better? The positive effects of biodiversity on the well-being of individuals visiting urban and peri-urban green areas. Landsc. Urban Plan. 2015, 134, 221-228. [CrossRef]

27. Kardan, O.; Gozdyra, P.; Misic, B.; Moola, F.; Palmer, L.J.; Paus, T.; Berman, M.G. Neighborhood greenspace and health in a large urban center. Sci. Rep. 2015, 5, 11610. [CrossRef] [PubMed]

28. Shanahan, D.F.; Lin, B.B.; Bush, R.; Gaston, K.J.; Dean, J.H.; Barber, E.; Fuller, R.A. Toward Improved Public Health Outcomes from Urban Nature. Am. J. Public Health 2015, 105, 470-477. [CrossRef] [PubMed]

29. Clark, N.E.; Lovell, R.; Wheeler, B.W.; Higgins, S.L.; Depledge, M.H.; Norris, K. Biodiversity, cultural pathways, and human health: A framework. Trends Ecol. Evol. 2014, 29, 198-204. [CrossRef] [PubMed]

30. Lindemann-Matthies, P.; Marty, T. Does ecological gardening increase species richness and aesthetic quality of a garden? Biol. Conserv. 2013, 159, 37-44. [CrossRef]

31. Haas, J.; Furberg, D.; Ban, Y. Satellite monitoring of urbanization and environmental impacts-A comparison of Stockholm and Shanghai. Int. J. Appl. Earth Obs. Geoinf. 2015, 38, 138-149. [CrossRef]

32. Seto, K.C.; Güneralp, B.; Hutyra, L.R. Global forecasts of urban expansion to 2030 and direct impacts on biodiversity and carbon pools. Proc. Natl. Acad. Sci. USA 2012, 109, 16083-16088. [CrossRef] [PubMed]

33. Sheng, Y.K.; Thuzar, M. Urbanisation in Southeast Asia: Issues and Impacts; Institute of Southeast Asian Studies: Singapore, 2012.

34. McDonald, R.I.; Forman, R.T.T.; Kareiva, P. Open space loss and land inequality in United States' cities, 1990-2000. PLoS ONE 2010, 5, e9509. [CrossRef] [PubMed]

35. Haaland, C.; Konijnendijk van den Bosch, C.C. Challenges and strategies for urban green-space planning in cities undergoing densification: A review. Urban For. Urban Green. 2015, 14, 760-771. [CrossRef]

36. Lin, B.B.; Fuller, R.A. FORUM: Sharing or sparing? How should we grow the world's cities? J. Appl. Ecol. 2013, 50, 1161-1168.

37. Dallimer, M.; Tang, Z.; Bibby, P.R.; Brindley, P.; Gaston, K.J.; Davies, Z.G. Temporal changes in greenspace in a highly urbanized region. Biol. Lett. 2011, 7, 763-766. [CrossRef]

38. Shwartz, A.; Turbé, A.; Julliard, R.; Simon, L.; Prévot, A.-C. Outstanding challenges for urban conservation research and action. Glob. Environ. Chang. 2014, 28, 39-49. [CrossRef]

39. Kowarik, I. Novel urban ecosystems, biodiversity, and conservation. Environ. Pollut. 2011, 159, 1974-1983. [CrossRef] [PubMed]

40. McKinney, M.L. Urbanization, biodiversity, and conservation. BioScience 2002, 52, 883-890. [CrossRef]

41. Shwartz, A.; Turbé, A.; Simon, L.; Julliard, R. Enhancing urban biodiversity and its influence on city-dwellers: An experiment. Biol. Conserv. 2014, 171, 82-90. [CrossRef]

42. Dearborn, D.C.; Kark, S. Motivations for conserving urban biodiversity. Conserv. Biol. 2010, 24, $432-440$. [CrossRef]

43. Güneralp, B.; Seto, K.C. Futures of global urban expansion: Uncertainties and implications for biodiversity conservation. Environ. Res. Lett. 2013, 8, 014025. [CrossRef]

44. Garbuzov, M.; Fensome, K.A.; Ratnieks, F.L.W. Public approval plus more wildlife: Twin benefits of reduced mowing of amenity grass in a suburban public park in Saltdean, UK. Insect Conserv. Divers. 2015, 8, 107-119. [CrossRef]

45. Dietrich, K. Urbane Gärten für Mensch und Natur: Eine Übersicht und Bibliographie; Bundesamt für Naturschutz: Bonn, Germany, 2014. (In German)

46. Gobster, P.H.; Nassauer, J.I.; Daniel, T.C.; Fry, G. The shared landscape: What does aesthetics have to do with ecology? Landsc. Ecol. 2007, 22, 959-972. [CrossRef]

47. Conrad, M.K.; Tischew, S. Grassland restoration in practice: Do we achieve the targets? A case study from Saxony-Anhalt/Germany. Ecol. Eng. 2011, 37, 1149-1157. [CrossRef] 
48. Kazmierczak, A.; Armitage, R.; James, P. Urban green spaces: Natural and accessible? The case of greater Manchester, UK. In Urban Biodiversity and Design; Müller, N., Werner, P., Kelcey, J.G., Eds.; Blackwell Publishing Ltd: Oxford, UK, 2010; pp. 381-405.

49. Irvine, K.N.; Devine-Wright, P.; Payne, S.R.; Fuller, R.A.; Painter, B.; Gaston, K.J. Green space, soundscape and urban sustainability: An interdisciplinary, empirical study. Local Environ. 2009, 14, 155-172. [CrossRef]

50. Standish, R.J.; Hobbs, R.J.; Miller, J.R. Improving city life: Options for ecological restoration in urban landscapes and how these might influence interactions between people and nature. Landsc. Ecol. 2013, 28, 1213-1221. [CrossRef]

51. Ahern, J.; Boughton, J. Wildflower meadows as sustainable landscapes. In The Ecological City; Platt, R.H., Rowntree, R.A., Muick, P.C., Eds.; University of Massachusetts Press: Amherst, MA, USA, 1994; pp. 172-187.

52. Unterweger, P.A.; Rieger, C.; Betz, O. The influence of urban lawn mowing regimes on diversity of Heteroptera (Hemiptera). Heteropteron 2017, 48, 7-21.

53. Hiller, D.; Betz, O. Auswirkungen verschiedener Mahdkonzepte auf die Heuschreckenfauna städtischer Grünflächen. Naturschutz Landsch. 2014, 46, 241-246. (In German)

54. Kricke, V.C.; Bamann, T.; Betz, O. Einfluss städtischer Mahdkonzepte auf die Artenvielfalt der Tagfalter. Naturschutz Landsch. 2014, 46, 52-58. (In German)

55. Venn, S.; Kotze, D.J. Benign neglect enhances urban habitat heterogeneity: Responses of vegetation and carabid beetles (Coleoptera: Carabidae) to the cessation of mowing of park lawns. Eur. J. Entomol. 2014, 111, 703-714. [CrossRef]

56. Witt, R. Das Haarer Modell. Stadt+Grün Das Gartenamt 2014. (In German). Available online: http://www. xn--bchelberg-q9a.de/buechelberg/downloads/2018/naturnahe_gruenpflege_haarer_modell.pdf (accessed on 6 February 2020).

57. Unterweger, P.A.; Ade, J.; Braun, A.; Koltzenburg, M.; Kricke, C.; Schnee, L.; Wastian, L.; Betz, O. Langfristige Etablierung extensiver Grünflächenpflege in Stadtgebieten; Bundesamt für Naturschutz: Bonn, Germany, 2013; pp. 89-94. (In German)

58. Ade, J.; Wolf-Schwenninger, K.; Betz, O. Auswirkungen der Wiesenmahd auf verschiedene Käferarten ausgewählter Grünflächen im Stadtgebiet Tübingens. Jahresh. Ges. Naturkunde Württ. 2012, 168, 199-216. (In German)

59. Wastian, L.; Unterweger, P.A.; Betz, O. Influence of the reduction of urban lawn mowing on wild bee diversity (Hymenoptera, Apoidea), Journal of Hymenoptera Research 2016, 49, 51-63.

60. Sattler, T.; Obrist, M.K.; Duelli, P.; Moretti, M. Urban arthropod communities: Added value or just a blend of surrounding biodiversity? Landsc. Urban Plan. 2011, 103, 347-361. [CrossRef]

61. Baur, B. Biodiversität; Haupt Verlag: Berne, Switzerland, 2010. (In German)

62. Streit, B. Verlust der biologischen Vielfalt. Über spekulative Zahlen und realisierbare Ziele. Forsch. Lehre 2010, 9, 654-656. (In German)

63. Balmford, A.; Bond, W. Trends in the state of nature and their implications for human well-being. Ecol. Lett. 2005, 8, 1218-1234. [CrossRef]

64. Thomas, J.A.; Telfer, M.G.; Roy, D.B.; Preston, C.D.; Greenwood, J.J.D.; Asher, J.; Fox, R.; Clarke, R.T.; Lawton, J.H. Comparative losses of British butterflies, birds, and plants and the global extinction crisis. Science 2004, 303, 1879-1881. [CrossRef]

65. MEA. Ecosystem and Human Well-Being: A Framework for the Assessment; Island Press: Washington, DC, USA, 2003.

66. Soga, M.; Gaston, K.J. Extinction of experience: The loss of human-nature interactions. Front. Ecol. Environ. 2016, 14, 94-101. [CrossRef]

67. Balvanera, P.; Pfisterer, A.B.; Buchmann, N.; He, J.-S.; Nakashizuka, T.; Raffaelli, D.; Schmid, B. Quantifying the evidence for biodiversity effects on ecosystem functioning and services. Ecol. Lett. 2006, 9, 1146-1156. [CrossRef] [PubMed]

68. Hooper, D.U.; Chapin, F.S.; Ewel, J.J.; Hector, A.; Inchausti, P.; Lavorel, S.; Lawton, J.H.; Lodge, D.M.; Loreau, M.; Naeem, S. Effects of biodiversity on ecosystem functioning: A consensus of current knowledge. Ecol. Monogr. 2005, 75, 3-35. [CrossRef]

69. Spehn, E.M.; Hector, A.; Joshi, J.; Scherer-Lorenzen, M.; Schmid, B.; Bazeley-White, E.; Beierkuhnlein, C.; Caldeira, M.C.; Diemer, M.; Dimitrakopoulos, P.G.; et al. Ecosystem effects of biodiversity manipulations in European grasslands. Ecol. Monogr. 2005, 75, 37-63. [CrossRef] 
70. Meurk, C.D.; Blaschke, P.M.; Simcock, R.C. Ecosystem services in New Zealand cities. In Ecosystem Services in New Zealand-Conditions and Trends; Dymond, J.R., Ed.; Manaaki Whenua Press: Lincoln, New Zealand, 2013; pp. 254-273.

71. Kowarik, I. Cities and Wilderness. A new perspective. Int. J. Wilderness 2013, 19, 32-36.

72. Meske, M. "Natur Ist für Mich Die Welt": Lebensweltlich Geprägte Naturbilder von Kindern; Springer VS: Wiesbaden, Germany, 2011. (In German)

73. Claßen, T.; Kistermann, T.; Schillhorn, K. Naturschutz und Gesundheitsschutz; Bundesamt für Naturschutz: Bonn, Germany, 2005. (In German)

74. Council of Europe. The European Landscape Convention, Article 1. Available online: https://rm.coe.int/ 1680080621 (accessed on 6 February 2020).

75. Unterweger, P.A.; Schrode, N.; Betz, O. Urban Nature: Perception and Acceptance of Alternative Green Space Management and the Change of Awareness after Provision of Environmental Information. A Chance for Biodiversity Protection. Urban Sci. 2017, 1, 24. [CrossRef]

76. Rovers, A.-K. Kulturelle Ökosystemdienstleistungen und Ansätze zu Ihrer Quantifizierung-Am Beispiel von Wald-; Bundesamt für Naturschutz: Bonn, Germany, 2012. (In German)

77. BMU. 2015 Nature Awareness Study, Population Survey on Nature and Biological Diversity; Federal Ministry for the Environment, Nature Conservation, Building and Nuclear Safety: Berlin, Germany, 2016.

78. Bonnes, M.; Uzzell, D.; Carrus, G.; Kelay, T. Inhabitants' and experts' assessments of environmental quality for urban sustainability. J. Soc. Issues 2007, 63, 59-78. [CrossRef]

79. Junge, X.; Schüpbach, B.; Walter, T.; Schmid, B.; Lindemann-Matthies, P. Aesthetic quality of agricultural landscape elements in different seasonal stages in Switzerland. Landsc. Urban Plan. 2015, 133, 67-77. [CrossRef]

80. Junge, X.; Lindemann-Matthies, P.; Hunziker, M.; Schüpbach, B. Aesthetic preferences of non-farmers and farmers for different land-use types and proportions of ecological compensation areas in the Swiss lowlands. Biol. Conserv. 2011, 144, 1430-1440. [CrossRef]

81. Lindemann-Matthies, P.; Junge, X.; Matthies, D. Experimental evidence for human preference of biodiversity in grassland ecosystems. Biol. Conserv. 2010, 143, 195-202. [CrossRef]

82. Nielsen, A.B.; Olsen, S.B.; Lundhede, T. An economic valuation of the recreational benefits associated with nature-based forest management practices. Landsc. Urban Plan. 2007, 80, 63-71. [CrossRef]

83. Dramstad, W.E.; Tveit, M.S.; Fjellstad, W.J.; Fry, G.L.A. Relationships between visual landscape preferences and map-based indicators of landscape structure. Landsc. Urban Plan. 2006, 78, 465-474. [CrossRef]

84. Van den Born, R.J.G.; Lenders, R.H.J.; De Groot, W.T.; Huijsman, E. The new biophilia: An exploration of visions of nature in Western countries. Environ. Conserv. 2001, 28, 65-75. [CrossRef]

85. Junge, X.; Jacot, K.A.; Bosshard, A.; Lindemann-Matthies, P. Swiss people's attitudes towards field margins for biodiversity conservation. J. Nat. Conserv. 2009, 17, 150-159. [CrossRef]

86. Stilma, E.S.C.; Smit, A.B.; Geerling-Eiff, F.A.; Struik, P.C.; Vosman, B.; Korevaar, H. Perception of biodiversity in arable production systems in the Netherlands. NJAS-Wagen. J. Life Sci. 2009, 56, 391-404. [CrossRef]

87. Lindemann-Matthies, P.; Bose, E. Species richness, structural diversity and species composition in meadows created by visitors of a botanical garden in Switzerland. Landsc. Urban Plan. 2007, 79, 298-307. [CrossRef]

88. Marshall, E.J.P.; Moonen, A.C. Field margins in northern Europe: Their functions and interactions with agriculture. Agric. Ecosyst. Environ. 2002, 89, 5-21. [CrossRef]

89. Lindemann-Matthies, P. Beasts or beauties? Laypersons' perception of invasive alien plant species in Switzerland and attitudes towards their management. NeoBiota 2016, 29, 15-33. [CrossRef]

90. Sikorski, P.; Wińska-Krysiak, M.; Chormański, J.; Krauze, K.; Kubacka, K.; Sikorska, D. Low-maintenance green tram tracks as a socially acceptable solution to greening a city. Urban For. Urban Green. 2018, 35, 148-164. [CrossRef]

91. Lindemann-Matthies, P.; Brieger, H. Does urban gardening increase aesthetic quality of urban areas? A case study from Germany. Urban For. Urban Green. 2016, 17, 33-41. [CrossRef]

92. Schüpbach, B.; Junge, X.; Lindemann-Matthies, P.; Walter, T. Seasonality, diversity and aesthetic valuation of landscape plots: An integrative approach to assess landscape quality on different scales. Land Use Policy 2016, 53, 27-35. [CrossRef]

93. Qiu, L.; Lindberg, S.; Nielsen, A.B. Is biodiversity attractive? —On-site perception of recreational and biodiversity values in urban green space. Landsc. Urban Plan. 2013, 119, 136-146. [CrossRef] 
94. Nassauer, J.I. Care and stewardship: From home to planet. Landsc. Urban Plan. 2011, 100, 321-323. [CrossRef]

95. Ode, A.; Miller, D. Analysing the relationship between indicators of landscape complexity and preference. Environ. Plan. B Plan. Des. 2011, 38, 24-40. [CrossRef]

96. Wiersbinski, N. Zur Gesellschaftlichen Akzeptanz von Naturschutzmaßnahmen: Materialienband; Bundesamt für Naturschutz: Bonn, Germany, 1998. (In German)

97. Akbar, K.F.; Hale, W.H.G.; Headley, A.D. Assessment of scenic beauty of the roadside vegetation in northern England. Landsc. Urban Plan. 2003, 63, 139-144. [CrossRef]

98. Nassauer, J.I. Culture and changing landscape structure. Landsc. Ecol. 1995, 10, 229-237. [CrossRef]

99. Perpeet, M. Landschaftserlebnis und Landschaftsgestaltung; Schriftenreihe des Institutes für Landespflege der Universität Freiburg: Breisgau, Germany, 1992. (In German)

100. Ulrich, R.S. Human responses to vegetation and landscapes. Landsc. Urban Plan. 1986, 13, 29-44. [CrossRef]

101. Appleton, J. The Experience of Landscape; John Wiley and Sons Ltd.: Hoboken NJ, USA, 1975.

102. Goddard, M.A.; Dougill, A.J.; Benton, T.G. Why garden for wildlife? Social and ecological drivers, motivations and barriers for biodiversity management in residential landscapes. Ecol. Econ. 2013, 86, 258-273. [CrossRef]

103. Diekmann, A. Empirische Sozialforschung. Grundlagen Methoden Anwendungen; Rowohlt Taschenbuch Verlag: Reinbek, Germany, 2007. (In German)

104. Unipark, version 2014; EFS Survey; Questback GmbH: Köln, Germany, 2014.

105. FREEIMAGES. Available online: https://de.freeimages.com/ (accessed on 6 February 2020).

106. Van der Jagt, A.P.N.; Craig, T.; Anable, J.; Brewer, M.J.; Pearson, D.G. Unearthing the picturesque: The validity of the preference matrix as a measure of landscape aesthetics. Landsc. Urban Plan. 2014, 124, 1-13. [CrossRef]

107. Scannell, L.; Gifford, R. Defining place attachment: A tripartite organizing framework. J. Environ. Psychol. 2010, 30, 1-10. [CrossRef]

108. Gustafson, P. Meanings of place: Everyday experience and theoretical conceptualizations. J. Environ. Psychol. 2001, 21, 5-16. [CrossRef]

109. Schmidt-Dumont, G. Ästhetische Kommunikation am Beispiel von Bildgestaltung und Bildrezeption im Bilderbuch. In Beiträge Jugendliteratur und Medien; Juventa Verlag: Weinheim, Germany, 1997; Volume 8, pp. 73-97. (In German)

110. Bühl, A. SPSS 23: Einführung in die Moderne Datenanalyse; Pearson Deutschland: München, Germany, 2016. (In German)

111. Hunziker, M. Die Bedeutungen der Landschaft für den Menschen: Objektive Eigenschaft der Landschaft oder individuelle Wahrnehmung des Menschen? Forum für Wissen 2010, 2010, 33-41. (In German)

112. Backhaus, N.; Reichler, C.; Stremlow, M. Alpenlandschaften? Von der Vorstellung zur Handlung; Synthesebericht NFP 48, Schweizer Nationalfonds zur Förderung der wissenschaftlichen Forschung SNF: Berne, Switzerland, 2007. (In German)

113. Daniel, T.C. Whither scenic beauty? Visual landscape quality assessment in the 21st century. Landsc. Urban Plan. 2001, 54, 267-281. [CrossRef]

114. Bourassa, S.C. The Aesthetics of Landscape; Belhaven Press: London, UK, 1991.

115. Home, R.; Bauer, N.; Hunziker, M. Cultural and biological determinants in the evaluation of urban green spaces. Environ. Behav. 2010, 42, 494-523. [CrossRef]

116. Hunziker, M.; Kienast, F. Potential impacts of changing agricultural activities on scenic beauty-a prototypical technique for automated rapid assessment. Landsc. Ecol. 1999, 14, 161-176. [CrossRef]

117. Kaplan, R.; Kaplan, S. The Experience of Nature: A Psychological Perspective; Cambridge University Press: New York, NY, USA, 1989.

118. Smith, B. European Vision and the South Pacific; Yale University Press: Connecticut, CT, USA, 1989.

119. Orians, G.H. Habitat selection: General theory and applications to human behavior. In the Evolution of Human Social Behavior, 1st ed.; Lockard, J., Ed.; Elsevier: Chicago, IL, USA, 1980; pp. 49-66.

120. Kaplan, S.; Kaplan, R.; Wendt, J.S. Rated preference and complexity for natural and urban visual material. Percept. Psychophys. 1972, 12, 354-356. [CrossRef]

121. Shephard, P. English reaction to the New Zealand landscape before 1850. In Pacific Viewopoint; Victoria University, Department of Geography: Wellington, New Zealand, 1969; p. 27. 
122. Hunziker, M.; Felber, P.; Gehring, M.; Buchecker, M.; Bauer, N.; Kienast, F. How do different societal groups evaluate past and future landscape changes? Results of two empirical studies in Switzerland. Mt. Res. Dev. 2008, 28, 140-147. [CrossRef]

123. Hunziker, M.; Hoffmann, C.; Wild, S. Die Akzeptanz von Raubtieren, Gründe und Hintergründe-Ergebnisse einer repräsentativen Umfrage in der Schweiz. For. Snow Landsc. Res. 2001, 76, 301-326. (In German)

124. Hunziker, M. The spontaneous reafforestation in abandoned agricultural lands: Perception and aesthetic assessment by locals and tourists. Landsc. Urban Plan. 1995, 31, 399-410. [CrossRef]

125. Jim, C.Y.; Shan, X. Socioeconomic effect on perception of urban green spaces in Guangzhou, China. Cities 2013, 31, 123-131. [CrossRef]

126. Fischer, L.K.; Honold, J.; Botzat, A.; Brinkmeyer, D.; Cvejić, R.; Delshammar, T.; Elands, B.; Haase, D.; Kabisch, N.; Karle, S.J.; et al. Recreational ecosystem services in European cities: Sociocultural and geographical contexts matter for park use. Ecosyst. Serv. 2018, 31, 455-467. [CrossRef]

127. Lindemann-Matthies, P. Perception of plant species richness by people with different nationalities-An experimental study. Landsc. Res. 2017, 42, 482-497. [CrossRef]

128. Botzat, A.; Fischer, L.K.; Kowarik, I. Unexploited opportunities in understanding liveable and biodiverse cities. A review on urban biodiversity perception and valuation. Glob. Environ. Chang. 2016, 39, 220-233. [CrossRef]

129. Jorgensen, A.; Hitchmough, J.; Dunnett, N. Woodland as a setting for housing-Appreciation and fear and the contribution to residential satisfaction and place identity in Warrington New Town, UK. Landsc. Urban Plan. 2007, 79, 273-287. [CrossRef]

130. Jorgensen, A.; Hitchmough, J.; Calvert, T. Woodland spaces and edges: Their impact on perception of safety and preference. Landsc. Urban Plan. 2002, 60, 135-150. [CrossRef]

131. Hunter, M.R.; Hunter, M.D. Designing for conservation of insects in the built environment. Insect Conserv. Divers. 2008, 1, 189-196. [CrossRef]

132. Kaplan, R. Employees' reactions to nearby nature at their workplace: The wild and the tame. Landsc. Urban Plan. 2007, 82, 17-24. [CrossRef]

133. Nassauer, J.I. Messy ecosystems, orderly frames. Landsc. J. 1995, 14, 161-170. [CrossRef]

134. Lindemann-Matthies, P.; Bose, E. How many species are there? Public understanding and awareness of biodiversity in Switzerland. Hum. Ecol. 2008, 36, 731-742. [CrossRef]

135. Tanner, T. Significant life experiences: A new research area in environmental education. J. Environ. Educ. 1980, 11, 20-24. [CrossRef]

136. Colléony, A.; Prévot, A.-C.; Saint Jalme, M.; Clayton, S. What kind of landscape management can counteract the extinction of experience? Landsc. Urban Plan. 2017, 159, 23-31. [CrossRef]

137. Wells, N.M.; Lekies, K.S. Nature and the life course: Pathways from childhood nature experiences to adult environmentalism. Child. Youth Environ. 2006, 16, 1-24.

138. Shwartz, A.; Cheval, H.; Simon, L.; Julliard, R. Virtual garden computer program for use in exploring the elements of biodiversity people want in cities. Conserv. Biol. 2013, 27, 876-886. [CrossRef] [PubMed]

139. Hofmann, M.; Westermann, J.R.; Kowarik, I.; Van der Meer, E. Perceptions of parks and urban derelict land by landscape planners and residents. Urban For. Urban Green. 2012, 11, 303-312. [CrossRef]

140. Todorova, A.; Asakawa, S.; Aikoh, T. Preferences for and attitudes towards street flowers and trees in Sapporo, Japan. Landsc. Urban Plan. 2004, 69, 403-416. [CrossRef]

141. Klimeczek, H.J. Umweltgerechtigkeit im Land Berlin-Zur methodischen Entwicklung des zweistufigen Berliner Umweltgerechtigkeitsmonitorings. UMID 2014, 2, 16-22. (In German)

142. Claßen, T.; Heiler, A.; Brei, B.; Hornberg, C. Stadtgrün und Gesundheit-ein Beitrag zur Debatte um soziale und räumliche Ungleichheit. UMID 2011, 2, 100-104. (In German)

143. Lubbe, C.S.; Siebert, S.J.; Cilliers, S.S. Political legacy of South Africa affects the plant diversity patterns of urban domestic gardens along a socio-economic gradient. Sci. Res. Essays 2010, 5, 2900-2910.

144. Martin, C.A.; Warren, P.S.; Kinzig, A.P. Neighborhood socioeconomic status is a useful predictor of perennial landscape vegetation in residential neighborhoods and embedded small parks of Phoenix, AZ. Landsc. Urban Plan. 2004, 69, 355-368. [CrossRef]

145. Hope, D.; Gries, C.; Zhu, W.; Fagan, W.F.; Redman, C.L.; Grimm, N.B.; Nelson, A.L.; Martin, C.; Kinzig, A. Socioeconomics drive urban plant diversity. Proc. Natl. Acad. Sci. USA 2003, 100, 8788-8792. [CrossRef] 
146. Martens, D.; Gutscher, H.; Bauer, N. Walking in 'wild' and 'tended' urban forests: The impact on psychological well-being. J. Environ. Psychol. 2011, 31, 36-44. [CrossRef]

147. Purcell, T.; Peron, E.; Berto, R. Why do preferences differ between scene types? Environ. Behav. 2001, 33, 93-106. [CrossRef]

148. Huynh, Q.; Craig, W.; Janssen, I.; Pickett, W. Exposure to public natural space as a protective factor for emotional well-being among young people in Canada. BMC Public Health 2013, 13, 407. [CrossRef] [PubMed]

149. White, M.P.; Alcock, I.; Wheeler, B.W.; Depledge, M.H. Would you be happier living in a greener urban area? A fixed-effects analysis of panel data. Psychol. Sci. 2013, 24, 920-928. [CrossRef] [PubMed]

150. Haviland-Jones, J.; Rosario, H.H.; Wilson, P.; McGuire, T.R. An environmental approach to positive emotion: Flowers. Evol. Psychol. 2005, 3, 104-132. [CrossRef]

151. Lindemann-Matthies, P. 'Loveable'mammals and 'lifeless' plants: How children's interest in common local organisms can be enhanced through observation of nature. Int. J. Sci. Educ. 2005, 27, 655-677. [CrossRef]

152. Heerwagen, J.H.; Orians, G.H. Humans, habitats, and aesthetics. In Biophilia Hypothesis; Kellert, S.R., Wilson, E.O., Eds.; Island Press: Washington, DC, USA, 1995; pp. 138-172.

153. Nassauer, J.I. The aesthetics of horticulture: Neatness as a form of care. HortScience 1988, 23, $973-977$.

154. Robert-Koch-Institut. Lebenszeitprävalenz von Heuschnupfen in Deutschland nach Altersgruppe im Jahr 2011; Statista, Inc.: New York, NY, USA, 2011. (In German)

155. Van Zanten, B.T.; Verburg, P.H.; Koetse, M.J.; van Beukering, P.J.H. Preferences for European agrarian landscapes: A meta-analysis of case studies. Landsc. Urban Plan. 2014, 132, 89-101. [CrossRef]

156. Soliva, R.; Bolliger, J.; Hunziker, M. Differences in preferences towards potential future landscapes in the Swiss Alps. Landsc. Res. 2010, 35, 671-696. [CrossRef]

157. Hunziker, M.; Felber, P.; Gehring, M.; Buchecker, M.; Bauer, N.; Kienast, F. Evaluation of landscape change by different social groups. Mt. Res. Dev. 2008, 28, 140-148. [CrossRef]

158. Jankovska, I.; Straupe, I.; Panagopoulos, T. Naturalistic forest landscape in urban areas: Challenges and solutions. In Proceedings of the 3rd WSEAS International Conference on Urban Planning and Transportation, Corfu, Greece, 22-24 July 2010.

159. Jim, C.Y.; Chen, W.Y. Perception and attitude of residents toward urban green spaces in Guangzhou (China). Environ. Manag. 2006, 38, 338-349. [CrossRef] [PubMed]

160. Luederitz, C.; Brink, E.; Gralla, F.; Hermelingmeier, V.; Meyer, M.; Niven, L.; Panzer, L.; Partelow, S.; Rau, A.-L.; Sasaki, R. A review of urban ecosystem services: Six key challenges for future research. Ecosyst. Serv. 2015, 14, 98-112. [CrossRef]

161. TEEB. TEEB Manual for Cities: Ecosystem Services in Urban Management. 2011. Available online: www.teebweb.org (accessed on 1 November 2019).

162. James, P.; Tzoulas, K.; Adams, M.D.; Barber, A.; Box, J.; Breuste, J.; Elmqvist, T.; Frith, M.; Gordon, C.; Greening, K.L. Towards an integrated understanding of green space in the European built environment. Urban For. Urban Green. 2009, 8, 65-75. [CrossRef]

163. Gill, S.E.; Handley, J.F.; Ennos, A.R.; Pauleit, S. Adapting cities for climate change: The role of the green infrastructure. Built Environ. 2007, 33, 115-133. [CrossRef]

164. O'Sullivan, O.S.; Holt, A.R.; Warren, P.H.; Evans, K.L. Optimising UK urban road verge contributions to biodiversity and ecosystem services with cost-effective management. J. Environ. Manag. 2017, 191, 162-171. [CrossRef]

165. Weber, F.; Kowarik, I.; Säumel, I. A walk on the wild side: Perceptions of roadside vegetation beyond trees. Urban For. Urban Green. 2014, 13, 205-212. [CrossRef]

166. Aronson, M.F.; Lepczyk, C.A.; Evans, K.L.; Goddard, M.A.; Lerman, S.B.; Maclvor, J.S.; Nilon, C.H.; Vargo, T. Biodiversity in the city: Key challenges for urban green space management. Front. Ecol. Environ. 2017, 15, 189-196. [CrossRef]

167. Vierikko, K.; Elands, B.; Niemela, J.; Andersson, E.; Buijs, A.; Fischer, L.K.; Haase, D.; Kabisch, N.; Kowarik, I.; Luz, A.C. Considering the ways biocultural diversity helps enforce the urban green infrastructure in times of urban transformation. Curr. Opin. Environ. Sustain. 2016, 22, 7-12. [CrossRef]

168. Jiang, Y.; Yuan, T. Public perceptions and preferences for wildflower meadows in Beijing, China. Urban For. Urban Green. 2017, 27, 324-331. [CrossRef]

169. Brun, M.; Di Pietro, F.; Bonthoux, S. Residents' perceptions and valuations of urban wastelands are influenced by vegetation structure. Urban For. Urban Green. 2018, 29, 393-403. [CrossRef] 
170. Mathey, J.; Arndt, T.; Banse, J.; Rink, D. Public perception of spontaneous vegetation on brownfields in urban areas-Results from surveys in Dresden and Leipzig (Germany). Urban For. Urban Green. 2018, 29, 384-392. [CrossRef]

171. Borgström, S.; Elmqvist, T.; Angelstam, P.; Alfsen-Norodom, C. Scale mismatches in management of urban landscapes. Ecol. Soc. 2006, 11, 16. [CrossRef]

172. Valkó, O.; Deák, B.; Török, P.; Kirmer, A.; Tischew, S.; Kelemen, A.; Tóth, K.; Miglécz, T.; Radócz, S.; Sonkoly, J. High-diversity sowing in establishment gaps: A promising new tool for enhancing grassland biodiversity. Tuexenia 2016, 36, 359-378.

173. Nassauer, J.I. Cultural sustainability: Aligning aesthetics and ecology. In Placing Nature: Culture and Landscape Ecology; Island Press: Washington, DC, USA, 1997; pp. 65-83.

174. BMZ. Perspektiven der Urbanisierung-Städte Nachhaltig Gestalten; BMZ-Informationsbroschüre 3, Bundesministerium für Wirtschaftliche Zusammenarbeit und Entwicklung, Öffentlichkeits-, Informationsund Bildungsarbeit: Berlin, Germany, 2014. (In German)

175. Wu, J. Urban sustainability: An inevitable goal of landscape research. Landsc. Ecol. 2010, 25, 1-4. [CrossRef]

176. Klugman, J. Human Development Report 2011. Sustainability and Equity: A Better Future for All. UNDP-HDRO Human Development Reports. 2011. Available online: https://papers.ssrn.com/sol3/papers.cfm? abstract_id=2294671 (accessed on 6 February 2020).

177. Garritt, J. 'Now Who Decided That?': Experts and the public in biodiversity conservation. In Proceedings of the PATH Conference, Edinburgh, Scotland, 4-7 June 2006.

178. Özgüner, H.; Kendle, A.D. Public attitudes towards naturalistic versus designed landscapes in the city of Sheffield (UK). Landsc. Urban Plan. 2006, 74, 139-157. [CrossRef]

179. Balram, S.; Dragićević, S. Attitudes toward urban green spaces: Integrating questionnaire survey and collaborative GIS techniques to improve attitude measurements. Landsc. Urban Plan. 2005, 71, 147-162. [CrossRef]

180. Breuste, J.H. Decision making, planning and design for the conservation of indigenous vegetation within urban development. Landsc. Urban Plan. 2004, 68, 439-452. [CrossRef]

181. Swiss Agency for the Environment, Forests and Landscape (Ed.) Landschaft 2020. Analysen und Trends; Grundlage zum Leitbild des BUWAL für Natur und Landschaft. Schriftenreihe Umwelt 352: Berne, Switzerland, 2003; (In German with English summary).

182. Lazo, J.K.; Kinnell, J.; Bussa, T.; Fisher, A.; Collamer, N. Expert and lay mental models of ecosystems: Inferences for risk communication. RISK: Health Saf. Environ. 1999, 10, 45-64.

183. Zaunbrecher, B.S.; Ziefle, M. Integrating acceptance-relevant factors into wind power planning: A discussion. Sustain. Cities Soc. 2016, 27,307-314. [CrossRef]

184. Gross, C. Community perspectives of wind energy in Australia: The application of a justice and community fairness framework to increase social acceptance. Energy Policy 2007, 35, 2727-2736. [CrossRef] 